${ }^{0}$ Entomologica Fennica. 15 December 2000

\title{
On the taxonomy of Seleucus Holmgren and the European species of Phrudinae (Hymenoptera: Ichneumonidae)
}

\author{
Veli Vikberg \& Martti Koponen
}

Vikberg, V. \& Koponen, M. 2000: On the taxonomy of Seleucus Holmgren and the European species of Phrudinae (Hymenoptera: Ichneumonidae). - Entomol. Fennica 11: 195-228.

A diagnosis of European Phrudinae is given and a key is presented for Seleucus cuneiformis Holmgren and eleven European species of Phrudinae. Seleucini Vikberg trib. nov. in Ctenopelmatinae is proposed for Seleucus Holmgren. Astrenis nigrifacies Vikberg sp. nov. (Finland, Sweden, England, Scotland, France), A. brunneofacies Vikberg sp. nov. (Finland, Sweden, England, Scotland, Germany, Italy), Phrudus compressus Vikberg sp. nov. (Finland, Sweden) and the males of A. paradoxus (Schmiedeknecht) and $P$. badensis Hilpert are described for the first time. All other species are redescribed, and new distributional data are reported. The dentation of the claws and the form and location of modified sensory structures on the subbasal flagellomeres are used as taxonomic characters. Pygmaeolus nitidus (Bridgman), Astrenis nigrifacies, A. brunneofacies, Phrudus defectus Stelfox, $P$. compressus and $P$. badensis were found to be associated with ageing logs of Pinus sylvestris L. and Picea abies (L.) H. Karst.

Veli Vikberg, Liinalammintie 11 as. 6, FIN-14200 Turenki, Finland; E-mail: veli.vikberg@mail.htk.fi

Martti Koponen, Department of Applied Zoology, P. O. Box 27 (Viikki C), FIN-00014 University of Helsinki, Finland; E-mail: martti.a.koponen@helsinki.fi

Received 28 February 2000, accepted 8 September 2000

\section{Introduction}

The Phrudinae are a small ichneumonid subfamily with twelve genera, of Palaearctic, Oriental, Ethiopian, Nearctic and Neotropic distribution (Townes 1971, Wahl 1993, Yu \& Horstmann 1997, Gauld 1997). Four genera occur in North and Central Europe: Astrenis Förster, Earobia Townes, Phrudus Förster and Pygmaeolus Hellén. A species of Phaestacoenitus Smits van Burgst has been described from Daghestan Republic north of the Caucasus mountains (Kasparyan 1983a) and this may be regarded as the fifth European genus of the Phrudinae. The genus Seleucus Holmgren, which was included in Phrudinae by Townes (1971), was later transferred to the subfamily Ctenopelmatinae (Kolarov 1987, Wahl 1993) but it remains easily confused with Phrudinae.

The present study deals with the taxonomy and the distribution of species of the above mentioned six genera in Europe, especially in Finland.

\section{Material and methods}

Specimens of the Phrudinae were collected in Finland mainly by sweeping the lower vegetation and bushes and by sucking the small parasitic wasps from the net with an 
aspirator. The authors have collected parasitic wasps mostly in southern Finland (the provinces $A b, N, T a$ and $S a$ ) during several decades and often during the whole season from early April to October. Rather few phrudine specimens were caught, because they are rarely encountered (Wahl 1993). On 30 July 1996 author VV found his first specimens of Phrudus badensis in Janakkala ( $T a)$. It soon became evident that a few species of Phrudinae can be found in large numbers around ageing logs of Pinus sylvestris L. and Picea abies (L.) H. Karst. In 1997 samples were regularly swept around the ageing logs in the railway station area of Janakkala, Turenki (Grid $27^{\circ} \mathrm{E}$ 6758:372) from the beginning of June to the middle of September. During bright sunshine the phrudines were found on bushes (Salix), deciduous trees (Betula, Tilia) and tall herbs on the shady side of logs.

All examined specimens of Seleucus (16) and Phrudinae (altogether 3310 of which 3290 European) are preserved in the following institutes, museums and private collections:

AEIG = American Entomological Institute, Gainesville, Florida (D. B. Wahl)

$\mathrm{CNCO}=$ Canadian National collection, Ottawa (J. T. Huber)

DAZH $=$ Department of Applied Zoology, University of Helsinki (M. Koponen)

$\mathrm{KHPC}=$ Klaus Horstmann collection, Theodor-BoveriInstitut für Biowissenschaften (Biozentrum), University of Würzburg (K. Horstmann)

KREC $=$ Kainuu Regional Environment Centre, Research Centre of Friendship Park, Kuhmo, Finland (M. Kuussaari, G. Varkonyi)

NHML $=$ Natural History Museum, London (M. G. Fitton, D. Notton, S. Lewis)

NMGS = Naturhistorisches Museum, coll. Gabriel Strobl, Admont, Austria (J. Götze)

NMSE = National Museums of Scotland, Edinburgh (M. R. Shaw)

NNML = Nationaal Natuurhistorisch Museum, Leiden, Netherlands (C. van Achterberg)

NRMS = Naturhistoriska Riksmuseet, Stockholm (L.A. Janzon)

RJPC = Reijo Jussila private collection, Paattinen, Finland (R, Jussila)

VVPC $=$ Veli Vikberg private collection, Turenki, Finland (V. Vikberg)

ZISP = Zoological Institute, Russian Academy of Sciences, Sankt-Petersburg (D. R. Kasparyan)

ZMHB $=$ Zoologisches Museum an der HumboldtUniversität zu Berlin (F. Koch)

ZMUH = Zoological Museum, University of Helsinki (A. Albrecht)

ZMUT = Zoological Museum, University of Turku

(S. Koponen and M. Saaristo) Diller)

ZSSM = Zoologische Staatssammlung, Munich (E.

Specimens were studied under a Leitz stereomicroscope at magnifications of $50 \mathrm{x}$ and $100 \mathrm{x}$; the light source being a halogen lamp of $12 \mathrm{~V} 20 \mathrm{~W}$ with a light beam width of 10 degrees. The beam was diffused by placing a piece of thick $(0.2 \mathrm{~mm})$ tracing acetate near the specimen (see Goulet \& Huber 1993). Descriptions and drawings were made by author VV. Measurements and drawings were made using a grid of squares (50x50, side $0.2 \mathrm{~mm}$ ) in one eyepiece. The length of the fore wing was measured from the distal lateral margin of the tegula to the wing apex in one wing. The number of flagellomeres was counted in both antennae, excluding the anellus. If a different count was found in the two antennae, the specimen was included in both flagellomere groups. The anellus was not included when the length of flagellomere 1 (postanellus) was measured. The length of the petiolus was measured from the insertion area of the extensor tendon to the level of the spiracles; the length of the postpetiolus was taken from there to the medial apex of metatergum 1 .

Body parts are named according to Townes (1969) and/or Goulet \& Huber (1993).

The abbreviations of the biogeographical provinces of Finland are the same as in the Fauna Entomologica Scandinavica, except that $K l$ (Karelia ladogensis) is used and not included in $\mathrm{Sa}$, and Obo (Ostrobottnia ouluensis) is used for ObS, Obu (Ostrobottnia ultima) is used for $O b N, L k k$ (Lapponia kittilensis) for $L k W$, and Lks (Lapponia sompiensis) for $L k E$.

\section{Results}

\subsection{European Phrudinae}

\subsubsection{Diagnosis of European Phrudinae}

Small ichneumonids, fore wing length 1.6-3.6 $\mathrm{mm}$. Clypeus broadly lenticular, separated from face by a groove, often somewhat swollen along apical margin. Malar space without a subocular sulcus. Mandible stout, weakly tapered distally, bidentate or rarely unidentate. Palpal formula 5:4 or 5:3. Head posteriorly with proboscidal fossa ventrally narrower than width across mandibular bases, so that gena and postgena extend internally to the base of the mandible and the hypostomal carina ends about 0.3 of length along mandible. Antenna rather short, filiform or slightly clavate, with 12-21 flagellomeres, without a median pale band; subbasal flagellomeres with modified sensory structures on outer surface. Pronotum moderately long, with anterior margin simple; epomia weak or absent. Notaulus short or absent, sternaulus absent; posterior transverse carina of mesosternum broadly interrupted in front of each mid-coxa. Propodeum usually areolated. Fore tibia with or without a tooth on outer side; tarsal claws simple or pectinate. Fore wing with or without an areolet, when present areolet irregularly pentagonal to rhombic, petiolate 
above; $2 \mathrm{~m}$-cu usually with a single moderately long bulla; hind wing with basal half of $\mathrm{M}+\mathrm{Cu} 1$ absent or nebulous. Metasoma anteriorly slightly depressed, with tergum 1 often slender anteriorly, with spiracle at, before or slightly behind the centre; glymma present or absent. Tergum 3 without a crease separating a laterotergite. Female subgenital plate small, sclerotized, not notched apically. Ovipositor projecting beyond apex of metasoma, apically thin, without a dorsal subapical notch.

Some European species of Cryptinae, Tersilochinae and Orthocentrinae resemble species of Phrudinae. Species of Cryptinae have sternaulus and $\mathrm{M}+\mathrm{Cu} 1$ is complete or nearly complete. Tersilochinae have metasomal tergum 1 with spiracles distinctly posterior to the centre and ovipositor with a dorsal subapical notch. All subfamilies can be distinguished using the key of Wahl (1993).

\subsubsection{Key to Seleucus cuneiformis and Europe- an species of Phrudinae}

1. Fore wing 4.1-6.0 $\mathrm{mm}$ long. Hind wing with vein $\mathrm{M}+\mathrm{Cu}$ complete. Frons with a medial keel. Flagellum strongly tapered towards apex (apical flagellomeres less than half as wide as flagellomere 1 , covered with long setae), with 24-30 flagellomeres. Fore tibia with tooth apically on dorsal margin. Metasoma of female very elongate, laterally compressed. Ovipositor sheath (Fig. 1) short (not projecting beyond apex of metasoma), broad, apically rounded, with hairs hardly discernable. Upper valve of ovipositor with dorsal subapical notch (Fig. 1)

Seleucus cuneiformis Holmgren

- Forewing 1.6-3.6 mm long. Hind wing with basal three fifths of vein $\mathrm{M}+\mathrm{Cu}$ nebulous or absent. Frons without a medial keel. Flagellum filiform or apically slightly clavate, with 12-21 flagellomeres. Fore tibia without tooth apically on dorsal margin, except in Phaestacoenitus and Pygmaeolus. Shape of female metasoma variable. Ovipositor sheath longer (projecting beyond apex of metasoma), narrow, distinctly hairy. Ovipositor apically thin, without dorsal notch (Phrudinae) .... 2

2. Metasomal tergum 1 broad, 1.1-1.6 as long as apically wide, with glymma present. Chitinized part of metasternum 1 short, medially not reaching the level of spiracle of tergum 1. All claws simple

- Metasomal tergum 1 rather narrow to nar-

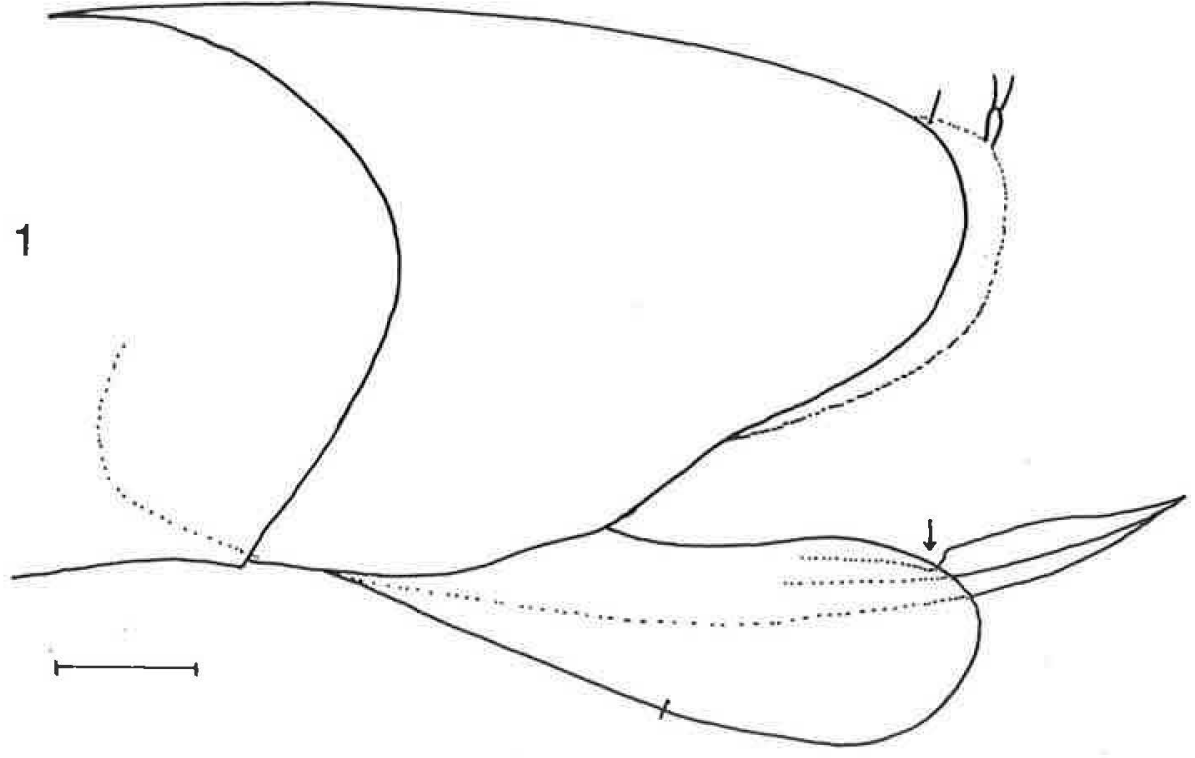

Fig. 1. Female of Seleucus cuneiformis Holmgren (Kunashir Island): apex of metasoma in lateral view. Scale line 0.1 $\mathrm{mm}$. 
row, 1.9-4.2 as long as wide, glymma absent. Chitinized metasternum 1 long, medially surpassing the spiracle of tergum 1. Claws pectinate, at least fore claws with teeth near base (Figs. 9-16) 5

3. Mandible unidentate. Antenna of female with 20-21 flagellomeres. Flagellomeres 46 each with a whitish tooth in hollow on apical 0.6 of segment (Fig. 3). Ovipositor sheath $0.59-0.69$ as long as fore wing. Fore wing 2.9-3.2 $\mathrm{mm}$ long. Laterotergite of metatergum 2 not separated by a crease. Areolet closed, broadly sessile above. Apex of fore tibia with a tooth on dorsal margin .....

.Phaestacoenitus niger nitidus Kasparyan

- Mandible with two teeth. Antenna with less than 18 flagellomeres. Ovipositor sheath much shorter than alternate. Fore wing less than $2.9 \mathrm{~mm}$ long. Metatergum 2 sometimes with a crease. Areolet sometimes open or obliterated. Apex of fore tibia sometimes without a tooth

4. Areolet closed, broadly sessile anteriorly. Propodeum with longitudinal and transverse carinae. Laterotergite of metasomal tergum 2 separated by a crease. Flagellomere 3 with large, oval sensilla in apical half (Fig. 2). Fore tibia without tooth or with only a very small tooth apically on dorsal margin........ Earobia paradoxa (Perkins)

- Areolet open or entirely missing, intercubitus short or obliterated by approximation of radius and cubitus. Propodeum without carinae, except sublateral longitudinal carina present posteriorly, posteromedially smooth, glabrous. Laterotergite not separated by a crease from dorsal part of metatergum 2. Flagellomeres (3)4-6(7) with small tooth on apical part of segment. Fore tibia with a clearly developed tooth apically on dorsal margin Astrenis nitidus (Bridgman)

5. Metasomal tergum 2 shortened laterocaudally, with spiracle near hind margin. Small teeth on distal half of subbasal flagellomeres (Fig. 4). Propodeum with high carinae, costula absent. Fore claws pectinate in basal part only and/or apex of claw clearly visible (Figs. 9-14). Fore tarsus longer than fore tibia (Astrenis Förster)

- Metasomal tergum 2 not or hardly shortened laterally, with spiracle near midlength of tergum. Small teeth on basal part of subbasal flagellomeres (Figs. 5-7). Propodeum with less high carinae, with costula present. Fore claws strongly pectinate to apex (as in Fig. 15). Fore tarsus shorter than fore tibia (Phrudus Förster) 9

6. Fore claws pectinate only on basal part, the most apical tooth longer than the others, almost at right angle to claw (Figs. 9-11). Face black or yellowish brown. Metatergum 2 laterally sometimes with a crease ( $A$. sinuatus group). 7

- Fore claw pectinate in apical half also, with subequal teeth (the most apical tooth not the longest one), apical teeth subparallel with apex of claw (Fig. 14). Face yellowish brown. Metatergum 2 laterally without a crease. Ocellar area and frons with rather thick pubescence (A. paradoxus group). 8

7. Face yellowish brown. Ocellar area and medial frons with few setae, with large glabrous areas. Posterior mesoscutum with a rather long medial keel. Metatergum 2 laterally without a crease. Pecten of claws weaker (Figs. 9-10), especially on mid- and hind claws ............... A. sinuatus (Roman)

- Face black, rarely medially indistinctly brownish. Ocellar area and medial frons with numerous, rather short setae. Posterior mesoscutum without a medial keel, sometimes with weak striae. Metatergum 2 laterally with a crease. Pecten of claws strong (Figs. 11-13) A. nigrifacies Vikberg sp. n.

8. Frons, vertex and gena black. Metasoma posterior to segment 1 black or brownish black. Metapleuron and metacoxa with fine, almost granulate microsculpture ...... A. brunneofacies Vikberg sp. $\mathrm{n}$. Head, except ocellar region, reddish to yellowish brown. Metasoma posterior to segment 1 brownish yellow. Metapleuron and metacoxa with rugose sculpture

A. paradoxus (Schmiedeknecht)

9. Flagellomeres 4-8 with long, curved dark spines which arise near basal margin of segment. Vertex and frons with few hairs, mostly glabrous and shining. Notauli not impressed on anterior mesoscutum. Areolet of fore wing closed, vein $3 \mathrm{r}-\mathrm{m}$ usually com- 

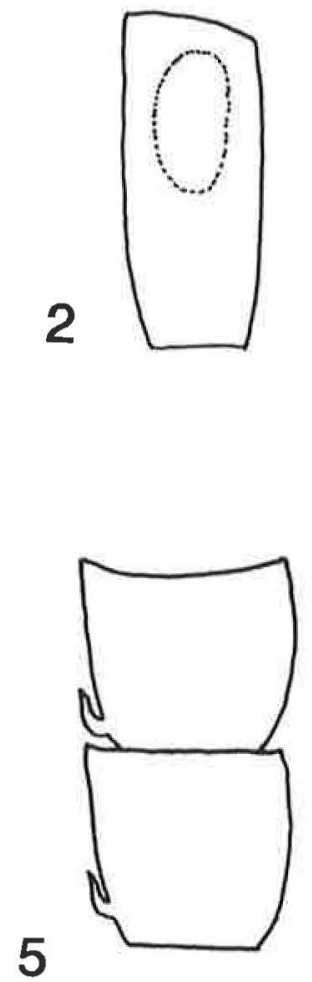
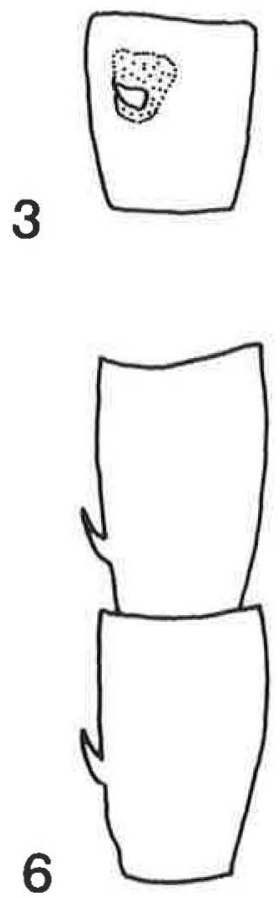
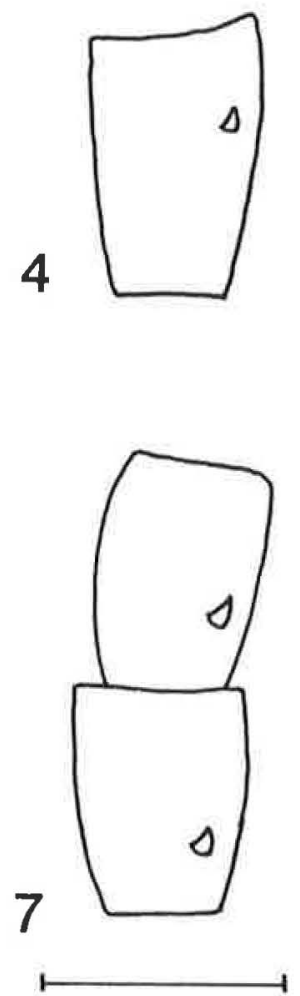

Figs. 2-7. Flagellomeres of Phrudinae to show modified sensory structures (apex above). Fig. 2. flagellomere 3 of Earobia paradoxa (Perkins), female paratype from Laimbach; Fig. 3. flagellomere 4 of Phaestacoenitus niger nitidus Kasparyan, holotype female: Fig. 4. flagellomere 4 of Astrenis brunneofacies Vikberg, male paratype from Vihti; Figs. 5-6. flagellomeres 4-5 of Phrudus monilicornis (Bridgman), female (Fig. 5) and male (Fig. 6) from Janakkala; Fig. 7. flagellomeres 4-5 of Phrudus defectus Stelfox, female from Janakkala. Scale line $0.1 \mathrm{~mm}$.

plete, although tubular posteriorly. Female: basal flagellomeres short, quadrate, subapical flagellomeres moniliform ( $P$. monilicornis group) .. P. monilicornis (Bridgman) Flagellomeres (3) 4-5 with short, white, teeth on basal $0.2-0.3$ of segment. Vertex and frons often with rather dense hairs. Notauli impressed anteriorly. Areolet of fore wing often open, with vein $3 \mathrm{r}-\mathrm{m}$ absent or present only anteriorly. Female: basal flagellomeres longer than broad, subapical flagellomeres not moniliform ( $P$. defectus group) ......... 10

10. Areolet of fore wing closed, with vein $3 \mathrm{r}-\mathrm{m}$ present throughout although weak posteriorly. Female: head, mesosoma and metasoma strongly laterally compressed. Head in dorsal view about 1.3-1.4 as long as wide. Male: head moderately compressed, in an- terior view about 1.05 as long as wide

P. badensis Hilpert

- Areolet of fore wing open, vein $3 \mathrm{r}$-m missing or present only anteriorly. Female and male: head not compressed, in dorsal view ca 1.6 as wide as long, in anterior view ca 0.86 as long as wide 11

11. Transverse carinae of propodeum strong, in lateral view posterior slope of propodeum not uniform but slightly angled above. Lateral carinae of petiolar area stronger than alternate, petiolar area shorter, ca 1.2 as long as wide. Female: metasoma posterior to segment 1 cylindrical or slightly depressed, in dorsal view metasomal tergum 2 about 0.6 as long as wide. Male: metasomal tergum 2 depressed, in dorsal view ca 0.7 as long as wide P. defectus Stelfox 


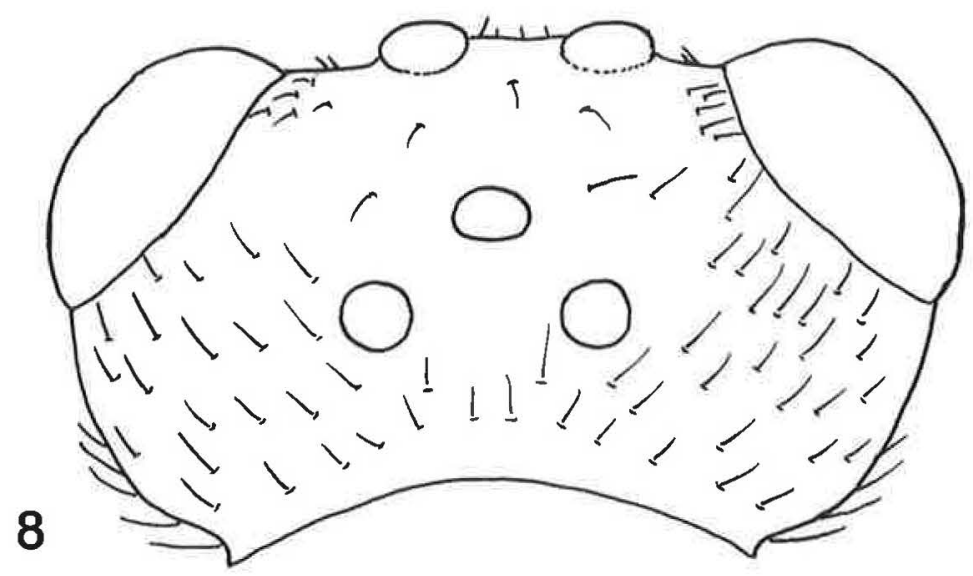

9
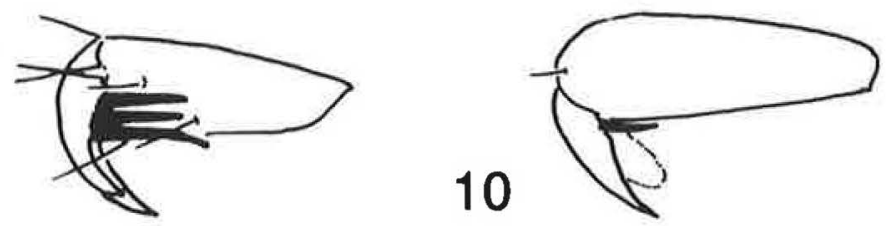

Figs. 8-10. Astrenis sinuatus (Roman). Fig. 8. head of male paralectotype in dorsal view; Fig. 9. fore tarsomere 5 in lateral view, lectotype female; Fig. 10. fore tarsomere 5 in lateral view, paralectotype male. Scale line $0.2 \mathrm{~mm}$ (Fig. 8) or $0.1 \mathrm{~mm}$ (Figs. 9-10).

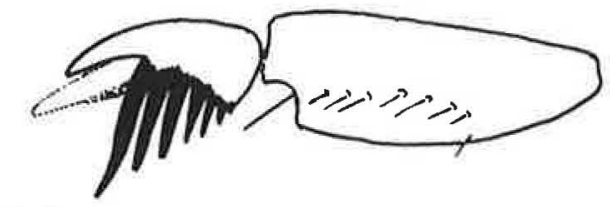

11

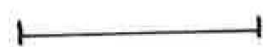

\section{2}

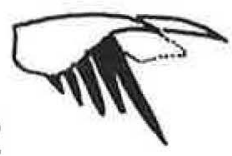
1

13

\section{4}

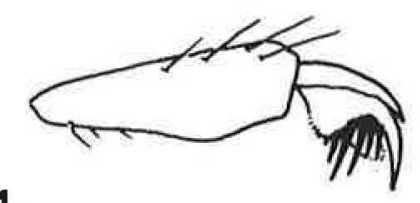

15

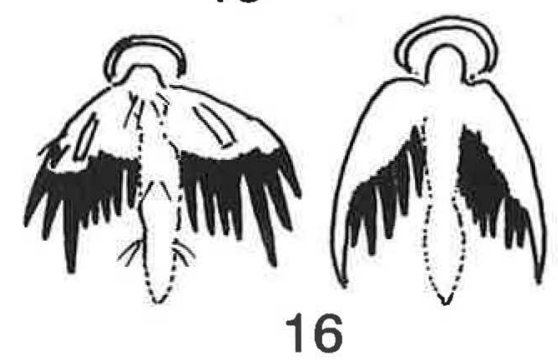

Figs. 11-16. Claws, some with tarsomeres, of species of Astrenis and Phrudus. Figs. 11-13. A. nigrifacies Vikberg, female paratype from Janakkala: fore tarsomere 5 with claw (Fig. 11), mid-claw (Fig. 12) and hind claw (Fig. 13); Fig. 14. fore tarsomere 5 with claw of $A$. brunneofacies Vikberg, paratype male from Shropshire; Figs. 15-16. hind claws of $P$. monilicornis (Bridgman) from Janakkala, male (Fig. 15) and female (Fig. 16). Scale line $0.1 \mathrm{~mm}$. 
Transverse carinae of propodeum and lateral carinae of petiolar area fine, in lateral view posterior slope of propodeum uniform to areola. Petiolar area longer and narrower, length/width ca 1.45. Female: metasoma strongly laterally compressed posterior to segment 1 , metasomal tergum 2 about 1.6 as long as wide in dorsal view. Male: metasoma less depressed, tergum 2 ca 1.25 as long as wide in dorsal view

P. compressus Vikberg sp. n.

\subsection{Seleucus Holmgren, 1860}

Seleucus Holmgren, 1860: 111. Type species: Seleucus cuneiformis Holmgren, by monotypy.

Only one Transpalaearctic species known, the generic characters are dealt with under it below.

The only other species described in the genus, Seleucus exareolatus Strobl, 1904, does not belong to Seleucus. According to the original description (Strobl 1904) the male has only 15 flagellomeres, frons with deep midfurrow, clypeus with apical tooth, apical flagellomeres thick and hardly longer than wide, fore wing without areolet; in all these characters not fitting with Seleucus. Possibly it is a species of Cryptinae. The holotype male from Austria, Admont could not be found in November 1999 in coll. G. Strobl (NMGS).

\subsubsection{Seleucus cuneiformis Holmgren, 1860 (Fig. 1)}

Seleucus cuneiformis Holmgren, 1860: 111. Lectotype female, selected by $\mathrm{H}$. Townes and designated by Kolarov (1987), labelled "K.K.", "Bhn.", "cuneiformis Holmgr.", "Lectotype Seleucus cuneiformis Hgn. Townes 58 "(NMRS). The type locality is Sweden, Västergötland, Kinnekulle (Boheman leg.).

Seleucus has been placed successively in "Fam. Ophionides" (Holmgren 1860), in Cryptinae, Stilpnini (Schmiedeknecht 1906, 1907, 1930), in Tryphoninae (Heinrich 1934), in Gelinae, Gelini (Townes et al. 1965), in Phrudinae (Hellén 1959, Townes 1971, Gauld 1997), and was transferred to Ctenopelmatinae, Mesoleiini by Kolarov (1987), and keyed separately as a ctenopelmatine genus by Wahl (1993). Yu \& Horst- mann (1997) treat it in Ctenopelmatinae, Mesoleiini. The female was figured in Heinrich (1934), Hellén (1959), in Townes (1971) and redecribed by Kolarov (1987), and the male was described and figured by Hellén (1959). Although Seleucus cuneiformis is rare in collections, it is known from the Palaearctic region from Sweden (Holmgren 1860), Poland (Brischke 1880, Heinrich 1937, Kazmierczak 1993), Finland (Hellén 1959), the Czech Republic (Šedivý 1989), the northwestern part of European Russia (Kasparyan 1981), Primorskiy kray in the Russian Far East (Kasparyan 1981) and Hokkaido in Japan (Uchida 1940, Townes et al. 1965)).

Seleucus cuneiformis does not fit into any of the eight tribes of Ctenopelmatinae (= Scolobatinae) in Townes (1970) and this is the reason why a new tribe Seleucini Vikberg trib. nov. is proposed for it. Below a redescription of the genus and the species based on 14 females and 2 males is given and at the same time in parenthesis compared with some characters of other tribes of Ctenopelmatinae as diagnosed by Townes (1970, as Scolobatinae).

Description of female. Lectotype: Fore wing $4.7 \mathrm{~mm}$ long, number of flagellomeres 26 .

Head black, especially vertex, temples and frons with bluish oily shine. Clypeus brownish black, palpi and mandibles yellowish brown, with teeth amber red. Antenna dark brownish, scape and pedicel may be paler. Mesosoma blackish, with brownish colouration on hind lower margin of pronotum, near wing bases, on epicnemium, mesepimeron and near insertion of hind coxa. Legs reddish yellow, tarsomeres 2-4 may have dark bases near joints, fore tarsomere 5 may be infuscate. Tegula brownish yellow, wings slightly yellowish, venation brown but costa brownish yellow, stigma dark brown with whitish base. Metasoma brownish black to brownish, ovipositor sheath brownish yellow.

Head 1.62 as wide as long in dorsal view, with temples subparallel behind eyes, in anterior view 0.84 as wide as high, punctate, hairy, between punctures smooth and shining, POL/OOL ca 0.66 . Frons with a strong medial keel from upper face to anterior ocellus. Eyes bare, with inner sides slightly converging below. Face strongly transverse, laterally with oblique rugae directed towards clypeus, which is faintly separated from 
face. Clypeus broadly lenticular in outline, convex in the transverse direction and flat in vertical direction, its margin thick, with a fringe of closely spaced bristles. Clypeal foveae impressed, almost linear and open. Mandible broad, with equal teeth, its outer surface with a strong subbasal transverse impression (as in some Pionini), its lower margin sharp subbasally. Malar space short, ca 0.26 as long as basal width of mandible, without sulcus. Genal carina complete, rather abruptly joining hypostomal carina distinctly above base of mandible. Antenna slender, strongly tapered apically. Flagellomere $1 \mathrm{ca} 2.2$ times as long as apically wide, 1.1 times as long as 2 (as in Pionini and Perilissini).

Mesosoma 1.7 as long as wide, 1.11 as high as wide. Pronotum laterally in the middle and speculum smooth, glabrous, thorax otherwise punctate, hairy, between punctures smooth, without surface sculpture. Epicnemial carina complete, its upper end reaching front edge of mesopleurum opposite middle of hind margin of pronotum. Notaulus very weak, present only anteriorly. Basal end of median and sublateral longitudinal carinae of propodeum separated from hind margin of metanotum by a deep, $u$-shaped notch (as in Pionini). Costula strong (never present in Mesoleiini). Areola weakly separated from basal and petiolar areas, areolar region with several transverse rugae. Propodeal spiracle shortly oval. Membranous flap on inner side of front tibial spur ending distally in a gradual taper or more abruptly rounded off (as in Pionini and Perilissini). Spurs of hind tibia slender, inner spur 0.6 as long as hind tarsomere $1,1.3$ as long as outer spur. Tarsal claws without pecten. Pterostigma ca 2.9 as long as wide, emitting radius beyond the middle ( 0.53$)$ of stig$\mathrm{ma}$. Areolet of fore wing irregular, quadrangular, anteriorly shortly petiolate, or sessile, acute or narrow, vein $3 \mathrm{r}$-m distinct, unpigmented posteriorly, unpigmented throughout, or present only anteriorly. Nervulus slightly postfurcal. Nervellus slightly inclivous, intercepted near posterior end, discoidella spurious.

Metasoma of the female highly modified, elongate, apically compressed, with minute hairs. Dorsal profile of metasomal tergum 1 weakly arched. Tergum $12.6-2.9$ as long as apically wide, with spiracles slightly behind the middle, glymma absent. Metasomal tergum 21.8 as long as wide in dorsal view, with thyridium absent. Epipleurum of metasomal tergum 2 folded under, with a crease present from base to spiracle only. Metasoma of female posteriorly strongly laterally compressed, compression beginning with tergum 3 which is medially 3.7 as long as wide in dorsal view. Terga 3-7 each with a deep excision posteromedially. Segments posterior of 3 are highly telescopable, their combined length may increase up to 3 times and the length of the metasoma can increase from $6 \mathrm{~mm}$ to $12 \mathrm{~mm}$ when they are fully extended. Ovipositor sheath (Fig. 1) short, as long as 0.08 of fore wing, slightly upcurved, broadening posteriorly, with small punctures, hairs hardly evident. Ovipositor rather narrow, slightly upcurved, with a distinct dorsal subapical notch (Fig. 1). Cercus of female arising close to dorsal edge of its tergum, very small, about 1.2 times as long as wide, its setae reduced.

Descritption of male. Length of body 6.2-7.5 $\mathrm{mm}$, of metasoma 3.4-4.1 mm. Colour as in female. Antenna as in female, without tyloids or other modified sensory structures.

Metasoma depressed, posteriorad of segment 12.7 as long as wide in dorsal view. Tergum 12.9 as long as apically wide, with spiracle slightly (0.52) posterior of middle. Postpetiolus 1.43 as long as wide. Tergum 21.6 as long as wide, with few very short hairs. Tergum 31.2 as long as wide, covered with rather long and dense hairs, tergum 2 and anterior part of tergum 3 to a little posterior of spiracle with sharp margin and crease. Tergum 4 and following terga transverse, covered with hairs. Cercus of male larger than in female, ca 2 times as long as wide, with several long setae.

Variation. The number of flagellomeres and corresponding length of fore wing (mean and observed range in $\mathrm{mm}$ ) are as follows:

$\begin{array}{lll} & \text { Flagellomeres, } & \text { fore wing } \\ \text { female; } & 24(\mathrm{n}=1) & 4.1 \mathrm{~mm} \\ & 26(\mathrm{n}=2) & 4.85(4.7-5.0) \\ & 27(\mathrm{n}=5) & 4.98(4.6-5.2) \\ & 28(\mathrm{n}=4) & 5.15(5.1-5.3) \\ & 29(\mathrm{n}=1) & 6.0 \\ & 30(\mathrm{n}=1) & 6.0 \\ \text { male; } & 25(\mathrm{n}=1) & 4.8 \\ & 27(\mathrm{n}=1) & 5.6\end{array}$

In many characters Seleucus fits within Pionini, but the structure of the ovipositor (distinct dorsal notch) is more similar to Perilissini, Meso- 
leiini and Euryproctini.

Specimens examined. Europe $\left(4+20^{*}\right)$. Finland, Sa: Ruokolahti, Patjasuo, Grid $27^{\circ} \mathrm{E} 680: 59,24.7 .19481$ 우 $10^{*}, 28.7 .1948$ (labelled 29.7.1948) 1 \%, leg. W. Hellén (ZMUH). Sweden, VG: Kinnekulle, two females (lectotype and paralectotype, NHRS). Germany, Niedersachsen, Einbeck, 5.8.1969 1\%, [leg. R. Hinz?] (ZSSM).

Asia (10 9 ). Russia, Primorskiy kray (territory): Khasan, W. Kedrovaya pad, 3.8.1978 1일. leg. Kasparyan (ZISP). Vladivostok, Sedanka, 3.9.1982 2\%, leg. Tobias (ZISP). Kamenushka, $30 \mathrm{~km}$ SE of Ussuriysk, 14.7.1981 1 \%, leg. Kasparyan (ZISP). $30 \mathrm{~km} \mathrm{NW}$ of Spassk-Dalniy, 25.8.1981 2\%, leg. Belokob. (ZISP). E. Ussur. station, 40 km SE of Chuguyevska, 23.8.1978 1 9 , leg. Kasparyan (ZISP). Sakhalinskaya oblast: S, Kuril islands, Kunashir island, Tretyakovo, 5.8.1973 1\%; 9.8.1973 2\%, leg. Kasparyan (ZISP).

Distribution. Czech Republic, Finland, Germany (new), Japan, Poland, Russia (the European part; the Russian Far East; the Kuril islands), and Sweden.

Biology. The specimens from S.E. Finland were captured in a grove inside a forest area far away from human habitation on 24 and 28("29") July, 1948 (Hellén 1959). The three specimens are covered with numerous yellowish, elongate, small pollen grains which indicate that they had visited flowers of an umbellifer, possibly Angelica sylvestris. This assumption is confirmed by the collecting notebooks of W. Hellén (in ZMUH), the code number labels on the insect pins tell that two specimens were caught on flower heads of Angelica. The female in Pistyn, East Carpathians, Poland was found in a ravine in fir wood at the end of July (Heinrich 1934). The male from Germany was captured on 5 August and the females from Russian Far East were captured between 14 July - 3 September. Otherwise the biology and the host are unknown.

Other species of Ctenopelmatinae are endoparasitoids of sawflies (Hymenoptera, Symphyta), as far as is known (except that some species of Lathrolestes parasitize on Eriocraniidae, Lepidoptera). The modified, flexible metasoma of the female is obviously an adaptation to oviposit into hosts far from the surface, probably to be found in late summer in forest areas.

\subsection{Phaestacoenitus Smits van Burgst, 1913}

Phaestacoenitus Smits van Burgst, 1913: 363. Type species: Phaestacoenitus demeyerei Smits van Burgst by monotypy.

Five species of this genus are known from the southern Palaearctic area: $P h$. demeyerei Smits van Burgst, known from the holotype female from Tunisia (Smits van Burgst 1913) and one male from Israel (Aubert 1976 as Ph. de-meyeri, Aubert et al. 1984), Ph. bidentator Aubert, 1979 from N.E. Turkey (Aubert 1979, Kolarov 1995) and Armenia (Kasparyan 1983a), Ph. caucasicus Kasparyan, 1983 from Azerbaijan and Georgia, $P h$. rufus Kasparyan, 1983 from S.E. Kazakhstan and Uzbekistan, and $P h$. niger Kasparyan, 1983 from Central Asia: Kazakhstan, Turkmenistan, Uzbekistan, Tajikistan and Kirghizia (Kasparyan 1983a). Two subspecies of $P h$. niger are known the Caucasus area: niger longicaudus Kasparyan, 1983 from Azerbaijan and niger nitidus Kasparyan, 1983 from Daghestan. The genus was characterized by Townes (1971) who mentioned and figured also one unnamed male from Israel (= Ph. demeyerei according to Aubert 1976) and by Kasparyan (1983a) who also figured some species and presented a key to the species of Phaestacoenitus.

The genus is characterized by unidentate mandible (except in Ph. bidentator), 3-segmented labial palpi, fore wing with sessile areolet, propodeum without carinae, metasomal tergum 1 short and broad with a glymma, and the long or rather long ovipositor sheath.

\subsubsection{Phaestacoenitus niger nitidus Kasparyan, 1983 (Fig. 3)}

Phaestacoenitus niger nitidus Kasparyan, 1983: 156. Holotype female: Russia, Daghestan Republic, 25 km NW Makhachala, desert of ephemerals and wormwood, 17.5.1972 leg. Kasparyan (ZISP).

Hitherto, only the holotype was known. A figure of the tip of the ovipositor is given in Kasparyan (1983a).

Description of female. Holotype: Length of fore wing $3.2 \mathrm{~mm}$. Number of flagellomeres 21 
(right) to 20 (left antenna). Body black. Clypeus medioapically brown. Mandible brown in the middle, amber red apically. Palpi dark brown. Antenna brownish black. Tegula brown. Wings whitish, with whitish hairs, venation and pterostigma dark brown, with a small whitish basal spot. Humeral plate, $\mathrm{C}+\mathrm{Sc}+\mathrm{R}$ basally and A yellowish. Coxae black, trochanters and trochantelli black to brownish black, femora reddish brown, basal 0.4 of mid-femur, basal 0.8 of hind femur blackish. Tibiae reddish brown, basally yellowish. Tarsi dark brown, fore tarsomeres 1-2 paler brown. Ovipositor sheath brownish black.

Head 0.57 as long as wide in dorsal view, with temples subparallel behind the eyes, 0.92 as high as wide in anterior view. POL/OOL 0.95. Eyes subparallel on frons and face. Face 2.3 as wide as high, clypeus separated by a distinct furrow. Clypeus 3.1 as wide as high. Frons and face punctured, interspaces faintly alutaceous, shining. Malar space 0.27 as long as width of base of mandible. Occipital carina complete, fused with hypostomal carina rather near mandible, the fused carina broad and shallow turning outwards to base of mandible. Flagellomeres 1-2(3) shorter and narrower than those following, subapical flagellomeres slightly elongate. Flagellomeres 4-6 each with a whitish tooth in hollow on apical 0.6 part of segment (Fig. 3).

Mesosoma 1.48 as long as wide, 1.16 as high as wide. Epomia absent. Fore tibia with hairs and small spines, distinctly shorter (0.67) than fore tarsus, dorsal margin with apical tooth. All claws simple. Hind femur 2.9 as long as high. Hind tibia 1.14 as long as hind tarsus, inner hind sporn short, 0.28 as long as hind tarsomere 1. Pterostigma wide, 2.1 as long as high, emitting radius before $(0.45)$ middle.

Metasomal tergum 1 flat, short, 1.23 as long as wide, with spiracle distinctly before $(0.35)$ middle, with glymma. Sternum 1 very short. Metasoma posterior to segment 11.84 as long as wide in dorsal view, slightly (1.13) broader than high. Tergum 2 transverse, 1.8 as wide as medially long, basal suture deep, large ovoid thyridia opposite to hind corners of postpetiolus, laterotergite not separated by a crease, spiracle low on laterotergite. Tergum 3 transverse, 2.1 as wide as long. Ovipositor sheath 1.9 as long as hind tibia. Ovipositor sheath/fore wing index 0.59 . Ovipositor rather thick, upcurved, in transverse section higher than wide. Upper valve without nodus, lower valve apically with ca 9 faint oblique transverse teeth, apex sharp, narrow.

Male. Unknown.

Variation. Another female from Georgia: Fore wing $2.9 \mathrm{~mm}$ long, 20 flagellomeres. Ovipositor sheath/fore wing index 0.69 .

Specimens examined. Russia, Daghestan Republic, the holotype female (see above). Asia: Georgia, Vashlov. zap., 20.5.1978 1ㅇ, leg. Kotenko (ZISP).

Distribution. Georgia (new), and Russia (Daghestan Republic).

Biology. The two known females were captured on the 17th and 20th of May, the holotype in desert of ephemerals and wormwood (Absinthium). Otherwise biology and host unknown.

\subsection{Pygmaeolus Hellén, 1959}

Pygmaeolus Hellén, 1959: 85-86. Type species: Thersilochus nitidus Bridgman, by monotypy.

Only one species in Europe. Near the S.E. border of Europe another species, P. turcicus (from Turkey) has been described by Kolarov (1993). The characters of the genus are given in the key.

\subsubsection{Pygmaeolus nitidus (Bridgman, 1889)}

Thersilochus nitidus Bridgman, 1889: 430. Possible holotype female, England. Wiltshire, Nunton (NHML) (Fitton 1976: 320).

The species was redescribed and figured by Hellén (1959) and Townes (1971). It has been recorded from Britain (Bridgman 1889, Morley 1915, Gauld \& Fitton 1980), Finland (Hellén 1959), Poland (Sawoniewicz 1982, 1986), Germany (Horstmann 1988), and Spain (Rey del Castillo 1991). One forewing resembling that of Pygmaeolus nitidus has been found as a fossil from the upper Miocene of Cerdanya Basin on the southern side of Pyrénées in Spain (Arillo \& Sanz de Bremond 1992).

Description of female (from Janakkala). Length of fore wing $2.1 \mathrm{~mm}$, antenna with 14 flagellomeres. Black. Clypeus, except infuscate base, mandible, except darker amber red teeth, malar space, scape and pedicel reddish brown. 
Flagellum brownish black, flagellomeres 1-3 paler, brown. Palpi and humeral plate pale brownish yellow. Tegula brownish black, venation of fore wing and pterostigma brown. Legs reddish brown, mid- and hind coxae infuscate basally, hind tibia and all tarsi dark brown. Ovipositor sheath dark brown.

Head transverse, 0.68 as long as wide in dorsal view, slightly converging backwards behind eyes, in anterior view 0.83 as long as wide. Vertex and frons with fine coriaceous sculpture, covered with short hairs, gena smooth behind eye but otherwise coriaceous. Face transverse, 2.5 as wide as medially high, face medially strongly convex, protruding, with hairs directed upwards. Clypeus strongly transverse, 3.8 as wide as high, shining with sparse punctures, its lower margin subtruncate medially, rather thick, punctate, with fringe of short hairs on lower hind margin. Malar space short, ca 0.25 as long as width of base of mandible. Mandible with lower tooth longer than upper tooth. Occipital carina complete, not joining hypostomal carina, both ending mesad of base of mandible. Flagellum thickening toward apex, all segments elongate. Flagellomere $1 \mathrm{ca} .0 .65$ as long as 2 . Small teeth on apical part (0.7) of flagellomeres (3) 4-6.

Mesosoma 1.5 as long as wide, 1.2 as high as wide. Epomia absent. Mesoscutum covered with thick, short hairs, notauli weakly impressed anteriorly, posteriorly the course of the notauli marked with coriaceous sculpture and small punctures, lateral lobes shining, punctate. Mesoscutellum without lateral carinae, posteriorly with dense microsculpture. Upper part of mesepisternum mainly smooth, shining, lower lateral part with coriaceous sculpture. Epicnemial carina rather weak, complete, usually reaching front margin of mesopleurum at the level of lower (0.3) hind margin of pronotum, lower anterior branch absent. Postpectal carina entirely absent. Propodeum without carinae, except for sublateral longitudinal carina posteriorly. Anterior end of propodeum and posterior side of metanotum forming a very shallow, v-shaped transverse furrow. Propodeal spiracles very small, subcircular. Pterostigma 2.4 times as long as wide, emitting radius from basal third. Areolet absent, intercubitus obliterated by approximation of radius and cubitus. Nervellus reclivous. Fore tibia apically with spinulae and a small tooth on dorsal side. Fore tarsus slender, 1.4 as long as fore tibia, fore claws small, shorter than arolium, without pecten. Hind femur 3.6 as long as high. Hind tibia 0.77 as long as hind tarsus, with inner spur short, slender, ca 0.27 as long as hind tarsomere 1.

Metasomal tergum 1 flat, low, 1.3 as long as wide, with spiracles anterior $(0.38)$ to middle and with small glymma anteriorly. Posterior part of petiolus 0.33 as high as wide. Postpetiolus 0.84 as long as wide. Metasternum 1 very short. Metasoma posterior of tergum 1 oval, 1.45 as long as wide in dorsal view. Metatergum 2 with rather large, oblique thyridiae, with spiracle before middle and without a crease, 0.50 as long as wide in dorsal view. Tergum 3 strongly transverse, 0.35 as long as basally wide. Ovipositor sheath narrow, slightly upcurved, 0.74 as long as hind tibia. Ovipositor slightly (1.1) longer than hind tibia, slightly upcurved, basal half thicker and darker, seen from below slightly widening in the middle, the apical part narrow, without a nodus.

Description of male (from Janakkala). Fore wing $1.95 \mathrm{~mm}$ long, antenna with 15 flagellomeres. Colour as in female, except clypeus totally reddish brown, flagellomeres 1-3 reddish brown, coxae not infuscate, metasomal tergum 2 and bases of terga 3-4 dark brown.

Head almost subparallel behind eyes, 0.62 as long as wide in dorsal view, 0.90 as high as wide in anterior view. Flagellum, including hairs, similar to female, flagellomeres 4-7 each with a small tooth on apical part of segment.

Mesosoma as in female.

Metasoma narrower than in female. Tergum 1 1.6 as long as wide, with spiracles at anterior 0.31 . Postpetiolus 1.02 as long as wide. Tergum 20.68 as long as wide, tergum 30.49 as long as wide. Metasoma posterior of tergum 12.0 as long as wide in dorsal view.

Variation. Small species, length of fore wing 1.7-2.1 mm. The number of flagellomeres and corresponding length of fore wing (mean and range, in $\mathrm{mm}$ ) are as follows:

$\begin{array}{lll} & \text { Flagellomeres, } & \text { fore wing } \\ \text { female; } & 13(n=3) & 1.80(1.7-1.9) \\ & 14(n=55) & 1.92(1.7-2.1) \\ \text { male; } & 15(n=2) & 2.00(2.0) \\ & 14(n=2) & 1.80(1.8) \\ & 15(n=23) & 1.87(1.7-2.0)\end{array}$


Head may be parallel behind eyes in female. Rarely face laterally has brownish colour. Sometimes metasoma posterior of tergum 1 brownish black in female, and even tergum 1 may be brownish in male. The areolet varies, intercubitus short or missing, vein $3 \mathrm{r}-\mathrm{m}$ often present anteriorly, in one female areolet closed by complete vein $3 \mathrm{r}-\mathrm{m}$ in one wing.

Note 1. Pygmaeolus was erroneously reported from the Eastern Palaearctic area in Townes et al. (1965) because Thersilochus minutus Bridgman, 1889 (now placed in Phradis Förster, Tersilochinae; see Horstmann 1971: 74) was confused with Thersilochus nitidus.

Note 2. The figure 27 of Pygmaeolus nitidus in Townes (1971) is inaccurate in two characters: flagellomere 1 is drawn about as long as 2, and in the hind wing vein $\mathrm{M}+\mathrm{Cu}$ is complete.

Specimens examined (altogether $599^{\circ} 23 \AA^{\circ}$ ). Finland (32 o 16 $160^{\circ}$. Al: Jomala, Möckelö, Grid $27^{\circ} \mathrm{E} 668: 10$, dry hill, 16.7.1926 2 \& $1 \sigma^{\star}$, leg. W. Hellén; Jomala, Ramsholmen, 668:10, hazel grove, 24.6.1953 1 o, leg. W. Hellén (ZMUH); Jomala, Jomalaby, 669:11, 6.7.1984 1 아 leg. V. Vikberg (VVPC). Saltvik, 6704:116, 30.6.1983, 1 ơ, leg. V. Vikberg (VVPC). Ab: Gustavs = Kustavi, 672:19, 1921, 1 오, leg. W. Hellén. N: Helsinki, Botanical garden (labelled Helsinge), 16.7.1915, 1 ㅇ, leg. W. Hellén (ZMUH). Ta: Janakkala, 6758:372, 24.6.1983, 1 우 3.7.1997 2 우 $2 \sigma^{*} ; 7.7 .199711$ ㅇ $3 \sigma^{\pi} ; 8.7 .19971$ 우 13.7 .19971 우;

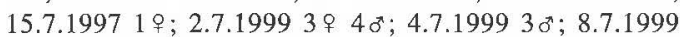
1 ㅇ $10^{*} ; 15.7 .19991$ 잉 leg. V. Vikberg (VVPC). Sa: Ristiina, 6826:502, 11.8.1987 1 б, leg. M. Koponen. Mikkelin mlk., 6830:501, 25.7.1976 1; 8.7.1979 1\%; 18.7.1987 1울 10.8.1987 19, leg. M. Koponen (DAZH). Russia, Leningrad oblast, Sosnovo, $70 \mathrm{~km} \mathrm{NW}$ of St. Petersburg, 8.7.1987 1 우 10 , leg. Kasparyan (ZISP). Jaroslavl oblast, Jaroslavl, 1 q, leg. Kokuyev (ZISP). EngIand $\left(17 \% 20^{\circ}\right)$. SD. Cornworthy, $1 \%$, Marshall Coll. (NHML). Surrey, Kew, low herbage, 26.6.1977 3 ㅇ $1 \%$, leg. V.F. Eastop (NHML, NMSE). Greater London, Wembley, 27.6.1939 3ㅇ, leg. K. Clarke (NHML). Northamptonshire, Spratton, Malaise trap, July $197510^{*}$, leg. I. \& P. Gauld (NHML). Cambridgeshire, Chippenham Fen, TL 650693, Malaise trap: carr at reedbed edge, 29.6.9.7.1984 1; 6.7.-20.7.1985 1이, leg. J. Ficld (NMSE). Norfolk, Santon Downham, TL 818883, Malaise trap: heath with birch and pine, 29.6.-9.7.1984 1\%; 20.6.25.6.1985 1우 ; 17.6.-26.6.1985 3우 25.6.-6.7.1985 1우; 6.7.-20.7.1985 1우 ; 30.7.1985 1ㅇ, leg. J. Field (NMSE). Scotland ( 3 \%). Perthshire, Pass of Killicrankie, 15.7.1977 2 , leg. Noyes, Rogers \& Huddleston (NHML). Inverness, Loch Garten, Malaise trap: Pinus and Betula, July 19841 ㅇ, leg. J. A. Owen (NMSE). Germany, Niedersachsen: Ostfriesische Inseln, Memmert,[yellow bowl], 23.6.-30.6.1986 1ㅇ, 30.6.-7.7.1986 1o , leg. V. Haeseler (KHUW). Bayern: Erching, Lk. Freising, 1.7.1968 2б; Mauern Kr. Neuburg, 6.7.1982 1; Taufkirchen bei München, 22.7.1968 19, leg. E. Haeselbarth (ZSSM).
Poland. Bialowieza, 8.7.1988 $2 \% 10^{\star}$, leg. M. Koponen. Distribution. Britain (England, Scotland), Finland, Germany, Poland, Russia (the European part, new), and Spain.

Biology. In southern Finland specimens have been captured from 24 June to 11 August, with a peak in the first half of July. Specimens from other countries are within the same period. Host unknown. Specimens from Janakkala (10 $\sigma^{\star} 19 \%$ ) were found near logs of Pinus and Picea by sweeping low herbage and bushes.

\subsection{Earobia Townes \& Townes, 1951}

Earobia Townes \& Townes, 1951:307. Type species: Earobia minor Townes \& Townes by original designation. Echthrolaricobius Perkins in Franz (1958:146). Type species: Echthrolaricobius paradoxus Perkins by original designation.

The genus is Holarctic and Oriental, with one species in America (minor) and one species in Europe and Taiwan (paradoxa). The characters of the genus are given in the key.

\subsubsection{Earobia paradoxa (Perkins, 1958) (Fig. 2)}

Echthrolaricobius paradoxus Perkins in Franz (1958:147). Holotype female: Switzerland, Zürich, Seegräben near Zürich, 24.5.1951, leg. J. Franz (NHML).

According to the original description females of this species are known from Switzerland, Zürich and Germany, Bavaria (Bayern). The male is unknown. Franz (1958) states that larvae were also found in Germany, Hessen, near Darmstadt. Later the species was reported from Taiwan (Chiu \& Wong 1987), Slovakia (Šedivý 1989) and Austria (Kazmierczak 1991).

Description of female. Paratype from Laimbach 28.5.1951: Length of fore wing $2.7 \mathrm{~mm}$, number of flagellomeres 17.

Head black, clypeus apically and palpi brownish yellow, the most basal segments yellow. Mandibles brownish yellow, with teeth amber red. Antennae blackish brown, scape, pedicel and flagellomeres 1-2 pale brown below. Mesosoma brownish black. Tegula brown, humeral plate yellowish brown. Legs brownish yellow, coxae 
basally infuscate, hind coxa mostly infuscate. Wings clear, venation brownish, pterostigma dark brown. Metasoma blackish brown.

Head transverse, in dorsal view 1.8 as wide as long, with temples slightly narrowing behind the eyes, in anterior view 1.3 as wide as high. Vertex and frons coriaceous, densely hairy, mat. POL/ OOL 0.92. Face transverse, 2.4 as wide as medially high. Upper face slightly protruding below antennae, face coriaceous, densely hairy, medially hairs directed upwards. Clypeus transverse, 3.3 as wide as high, shining, punctate, with long hairs, lower margin subtruncate, blunt. Malar space 0.9 as long as basal width of mandible. Upper tooth of mandible longer than lower. Maxillar palpus 5-segmented, labial palpus 3 segmented. Occipital carina complete, joining hypostomal carina above and mediad of mandibular base, the joined carina turning outwards to base of mandible. Flagellum slightly thickening towards apex, flagellomeres 1-3 slightly increasing in length, ca 2 times as long as wide. Flagellomere 3 with a large, oval, whitish, impressed area located largely in apical half (Fig. 2). Preapical segment slightly transverse.

Mesosoma 1.35 as long as high, 1.7 as long as wide. Epomia faintly developed. Mesoscutum densely hairy, notauli faintly impressed anteriorly but their course indicated by coriaceous microsculpture which extends posteromedially to the scuto-scutellar fovea. Scutellum mostly shining, convex, with carinae only anterolaterally. Upper part of mesepisternum coriaceous, speculum smooth and polished. Epicnemial carina complete, reaching anterior margin of mesepisternum, the lower anterior branch absent. Posterior mesosternal carina absent. Submetapleural carina complete. Areolet closed, oblique, second recurrent vein with one bulla anteriorly, posterolateral angle of second discoidal cell slightly acute. Nervulus postfurcal, nervellus intercepted in posterior third, slightly inclivous, discoidella weak. Legs slender, claws simple. Fore tibia shorter $(0.84)$ than fore tarsus, apically with a minute spine. Hind femur 4.5 as long as high. Hind tibia shorter (0.9) than hind tarsus, with slender inner spur 0.33 as long as hind tarsomere 1 . Propodeum hairy, almost completely areolated by rather fine carinae, costula absent and basal area fused with areola, spiracle very small, round.
Metasomal tergum 1 flattened, 1.5 as long as apically wide, with large glymma, its small spiracle situated near anterior third, surface coriaceous to striate, hairy. Postpetiolus as long as wide. Chitinized part of sternum 1 short, medially not reaching the level of spiracle. Metasoma beyond tergum 1 in dorsal view 1.8 as long as wide, anteriorly depressed, broadest at apex of tergum 2 , apically slightly laterally compressed. Tergum 2 transverse, 1.6 as wide as medially long, smooth, densely hairy, thyridiae absent, epipleura separated by crease, spiracle in anterior 0.4 . Tergum 3 1.8 as wide as long, without a crease. Terga 4-5 transverse, short, following terga telescoped inside them. Ovipositor sheath slightly upcurved, densely hairy, 0.6 as long as hind tibia. Ovipositor apically very thin, slightly upcurved, as long as hind tibia.

Male. Unknown.

Variation. All 5 studied females had 17 flagellomeres, and the length of fore wing had a mean of $2.67 \mathrm{~mm}$ and range of 2.6-2.8 mm. According to Perkins (1958) one female out of twelve had 16 flagellomeres. The base of the antenna can be dark all over. The spine on the dorsal margin of the fore tibia can be much reduced or even absent.

Specimens examined. Germany. Bayern, Laimbach near Munich, ex Laricobius erichsonii Rosenh., 24.5.1951 1 i (paratype), 28.5.1951 1 ㅇ (paratype), 7.5.1952 1 ㅇ (paratype), leg. T. Franz (coll. NHML). Switzerland, Seegraeben near Zurich, ex Laricobius erichsonii, 24.5.1951 1 우 (paratype), 28.5.1951 1 우 (paratype), leg. T. Franz (NHML).

Note 1 . The female specimen reported from Taiwan was examined; it is labelled Meifeng, Taiwan, 2150 m, 26 April,1983, leg. Henry Townes, Earobia paradoxus Perkins S.C. Chiu 1988 (coll. AEIG). It is now without wings, except for one hindwing, and the antennae are broken (Length of fore wing $2.6 \mathrm{~mm}$ and 17 flagellomeres according to Chiu \& Wong (1987)). It is rather similar to the European specimens but the legs are darker with hind femur and tibia infuscate, the hairs on basal flagellomeres are longer, and the nervellus is vertical and not intercepted with the discoidella practically absent. Further specimens are needed to evaluate the status of the Taiwanese population.

Note 2. One female and one male paratype of Earobia minor were examined from U.S.A.: The 
female is labelled Ithaca, N.Y., 15 May,1935, leg. H.K. Townes and the male is from the same locality on 8 May, 1934 (coll. AEIG). The female is smaller, length of fore wing $2.35 \mathrm{~mm}$, number of flagellomeres 16 (right antenna) and 17 (left). The legs are paler: hind coxa brownish yellow and hind tibia pale yellowish. Tergum 2 has coriaceous to weak striate sculpture. The base of the antenna is a little paler. Otherwise similar to the European specimens and very close to them. The male specimen has fore wing $2.7 \mathrm{~mm}$ long and number of flagellomeres 18 . Oval impressed sensillum on 3rd flagellomere as in female. Fore leg, including coxa, brownish yellow. Other legs and metasoma missing.

Distribution. Austria, Germany, Slovakia, Switzerland, and Taiwan.

Biology. This is the only European species of Phrudinae with known biology and host, discovered by Franz (1958). The host is the larva of Laricobius erichsonii Rosenhauer (Coleoptera, Dermestoidea, Derodontidae) which feeds as a predator on the eggs of chermesids, preferably Adelges piceae (Ratzeburg) (Homoptera, Phylloxeroidea, Adelgidae) on trunks of Abies spp. Earobia females fly around the tree and walk on the bark of trunks and attack only the 3rd or 4th instar beetle larvae from the middle of May to the middle of June. The host is usually struck on the lateral or ventral part of the last third of the abdomen and becomes temporarily paralyzed, in successful attacks the ovipositor remains inserted about 20 seconds. The ichneumonid larva hatches rather quickly but remains small while the host larva continues to feed on the trunk. Fully grown host larvae drop to the forest floor litter and the parasitoid larvae grow rapidly, devouring the entire host larva except for its cuticle in 13-17 days. The phrudine larva then breaks out of the host skin and spins a whitish cocoon on the forest floor that is about $2.75 \mathrm{~mm}$ long and studded externally with soil particles. The adult females emerge in the following spring.

\subsection{Astrenis Förster, 1869}

Astrenis Förster, 1869: 148. Type species: Hambergiella sinuata Roman, designated by Perkins, 1962: 408. Mengersenia Schmiedeknecht, 1907: 606. Type species:
Mengersenia paradoxa Schmiedeknecht, by monotypy. Hambergiella Roman, 1909: 359. Type species: Hambergiella sinuata Roman, by monotypy.

Astrenis Förster was recognized as a valid genus by Perkins (1962), who regarded Mengersenia as a valid genus too. Perkins (1962) treated Astrenis as feminine but the Code favours masculine gender in this case so we treat it as masculine. Roman (1914) regarded Hambergiella as synonymous with Mengersenia. Both were included in Phrudus by Townes (1971), Gauld \& Fitton (1980) and Kasparyan (1981). In their treatment of Phrudinae of Taiwan, Chiu \& Wong (1987) regarded Astrenis as a valid genus. Obviously the ichneumonid workers in Gauld \& Bolton (1988) accepted Astrenis as valid because they write that Phrudinae is represented in Britain by five rather uncommon species in three genera. Yu \& Horstmann (1997) catalogued Astrenis as a valid genus. Gauld (1997) listed the World genera of Phrudinae, but he did not mention Astrenis.

Characters to distinguish Astrenis from Phrudus are given in the key. In addition in Astrenis the slender petiole of the metasoma bears some anterolaterally directed hairs on the lower margin that are missing in species of Phrudus.

The genus is known from the Holarctic and Oriental regions. From the Nearctic area one species has been described as Orona petiolaris by Cameron (1905), and from Taiwan two species are known: Astrenis granum Chiu and $A$. densa Chiu in Chiu \& Wong (1987).

The European species can be divided into two species-groups: the sinuatus-group (sinuatus and nigrifacies) and the paradoxus-group (paradoxus and brunneofacies). These species-groups can be separated from each other by the characters given in the key.

\subsubsection{Astrenis sinuatus (Roman, 1909) (Figs 8- 10)}

Hambergiella sinuata Roman, 1909: 361. Lectotype female hereby designated: Sweden, Lule Lappmark, Sarek National Park, northern side of Rapadalen, 21.8.1904 leg. A. Roman (NHRS). The lectotype is labelled: "LuL, 1904", "21/8, A Rn”, "Lectotypus Hambergiella sinuata Roman 1909 \&, Hilpert, 1987’'[red label], "Hambergiella sinuata Rn o o" [white, handwritten label]. The female is glued on its left side at the corner of a triangular piece of paper; the left wings are missing and the right hind- 
wing is glued separately on the same paper piece, otherwise in moderate condition.

Description of female. Lectotype: Length of fore wing $2.9 \mathrm{~mm}$, antennae with 14(15)-15 flagellomeres (right antenna first).

Black. Face yellowish brown, clypeus, mandibles except amber red teeth, and palpi brownish yellow. Clypeus basally, scape, pedicel and flagellomere 1 yellowish brown, antenna apically brown. Legs brownish yellow, fore tarsomere 5 and hind coxa basally infuscate. Hind femur brownish, hind tibia apically and hind tarsomeres 1-2 slightly infuscate. Tegula brown, humeral plate yellowish brown, pterostigma brown.

Head 1.5 as wide as long in dorsal view, with temples narrowing behind eyes, in anterior view 0.85 as long as wide. Vertex and frons smooth, shining, with rather long and sparse hairs, upper frons medially largely glabrous. POL/OOL 0.61 . Eyes nearly glabrous, with their inner margins converging ventrad on frons, subparallel on face. Face smooth, with dense hairs, medially all hairs directed ventrad. Clypeus distinctly separated from face by a groove, transverse, similar to that of A. brunneofacies. Flagellomeres (2)3-6 with small tooth on apical (0.7) part of segment.

Mesosoma 1.7 as long as wide, 1.3 as high as wide. Epicnemial carina not reaching anterior margin of mesopleuron. Mid-lobe of mesoscutum densely hairy anteriorly, posteriorly with sparse hairs, lateral lobes largely glabrous. Mesoscutum with $0.2 \mathrm{~mm}$ longitudinal keel posteromedially and with some weaker striae. Mesoscutellum margined to apex, lateral slopes densely striate. Fore tibia without tooth apically on dorsal margin, slightly (1.05) longer than fore tarsus. Fore tarsomere 5 (Fig. 9) thickened, claw with dark teeth basally, the most apical tooth the longest, arolium slightly shorter than claw. Midclaw with pale teeth near the base. Hind femur 5.6 as long as high. Hind tibia longer (1.1) than hind tarsus, inner spur slender, 0.36 as long as hind tarsomere 1. Pterostigma 3.2 as long as wide, emitting radius slightly $(0.48)$ before middle.

Metasomal tergum 12.6 as long as wide, with spiracle before middle $(0.45)$. Tergum 2 medially half as long as tergum $1,0.7$ as long as wide in dorsal view, with convex hind margin, laterally shortened, with spiracle near hind margin. Tergum 3 nearly 1.6 as long as tergum 2 , ca 0.75 as long as wide. Tergum 4 strongly transverse. Ovipositor sheath narrow, 0.3 as long as metatibia.

Description of male. Paralectotype: 17 flagellomeres, length of fore wing $3.1 \mathrm{~mm}$.

Colour as in female except flagellum paler, brownish yellow to yellowish brown. Frons (Fig. 8) medially mostly glabrous, lower frons with 3 hairs directed upwards. Gena largely glabrous behind eyes, posteriorly with few hairs. Face smooth, hairy, all medial hairs directed downwards. Face 1.7 as wide as medially long. Clypeus 2.9 as wide as medially long, anterior margin rounded, medially subtruncate, anteriorly with a brown spinulose zone with a row of hairs. Clypeal fovea large, oval, open. Malar space about half as long as width of base of mandible. Upper tooth of mandible a little longer than lower. Flagellomeres 2-7 each with a small tooth. Keel on mesonotum $0.25 \mathrm{~mm}$ long. Fore tarsomere 1 (Fig. 10) enlargened, with claw having only one rather weak tooth basally. Spiracles on metasomal tergum 1 slightly protruding, about $(0.52)$ in the middle of tergum. Tergum 13.2 as long as wide. Petiolus 2.5 as long as wide, 0.80 as high as wide, ventrolaterally with some hairs directed anterolaterally. Postpetiolus 1.55 as long as apically wide. Tergum 20.5 as long as tergum $1,0.68$ as long as wide, no crease, no thyridia. Tergum 3 broadest, 0.60 as long as wide. Tergum 4 and following segments more or less telescoped inside anterior terga.

Variation. The number of flagellomeres and corresponding length of fore wing (mean and range, in $\mathrm{mm}$ ) are as follows:

$\begin{array}{lll} & \text { Flagellomeres, } & \text { fore wing } \\ \text { females; } & 14(\mathrm{n}=3) & 2.68(2.25-2.9) \\ & 15(\mathrm{n}=4) & 2.98(2.9-3.2) \\ & 16(\mathrm{n}=6) & 3.11(2.85-3.3) \\ \text { male; } & 17(\mathrm{n}=3) & 3.23(3.1-3.3) \mathrm{S} \\ & 14(\mathrm{n}=1) & 2.5 \\ & 16(\mathrm{n}=2) & 2.83(2.75-2.9) \\ & 17(\mathrm{n}=2) & 3.08(3.05-3.1)\end{array}$

Note 1. Since its description this species has been confused with $A$. nigrifacies and $A$. brunneofacies, for example in Britain by Carr (1924; but the locality of his record is in doubt because many of his specimens are of continental origin (Perkins 1953:117)) and Gauld \& Fitton (1980). The record from Abisko National Park, N. Sweden (Roman 1931) is confirmed by new speci- 
mens from there.

Note 2. The earlier reports of Mengersenia sinuata from Finland by Hellén (1942:87) and Phrudus sinuatus from Finland by Jussila (1984:93) were based on misidentifications of $A$. nigrifacies and $P$. defectus respectively.

Specimens examined (total 13 \% 6 $0^{\circ}$ ). Finland. Lkk (= KemL): Kolari, 7502:382, window trap 2.8.-23.8.1988, 10 leg. J. Siitonen (DAZH). Sweden. LU: Sarek National Park, Rapadalen, 1 ㅇ (lectotype; see above); 21.8.1904 $10^{*}$ (paralectotype) labelled "Lectoparatypus Hambergiella sinuata Roman 1909 o Hilpert, 1987"[red label], leg. A. Roman (NHRS). TO: Abisko, $400 \mathrm{~m}, 31.7 .19601$ o 1 , 1.8.19601, 6.8.196016 9, leg. W. R. M. Mason (CNCO). England, Gloucester, Staunton, High Meadow Wds., 9.6.1936 10, 11.6.1936 1\%, leg. E. B. B. \& J. F. P. (NHML).

Distribution. Britain (England), Finland (new), and Sweden.

Biology. Only a few specimens have been captured from 9 June (England) to 21 August (Swedish Lapland). Host unknown.

\subsubsection{Astrenis nigrifacies Vikberg sp. nov. (Figs 11-13)}

Description of female. Holotype: Length of body $2.75 \mathrm{~mm}$, of fore wing $2.8 \mathrm{~mm}$. Body black. Clypeus brown, infuscated basally. Mandibles yellowish brown, palpi brownish yellow. Scape, pedicel brownish yellow, flagellum brownish black, flagellomeres 1-2 paler. Tegula brown, pterostigma dark brown. Legs brownish yellow, fore tarsomere 5 slightly infuscate. Hind coxa black basally, hind femur brownish. Claws with black teeth.

Head 1.8 times as wide as long in dorsal view, with temples narrowing behind eyes, in anterior view 0.83 as high as wide. Vertex and frons smooth, shining, with slight microsculpture between posterior ocelli. POL/OOL 0.67. Vertex and frons with rather short hairs, upper frons with a large glabrous area medially. Eyes rather large, nearly glabrous (with some minute setae), with their inner margins converging ventrad on frons, subparallel on face. Face smooth, with thick hairs, transverse, 2.0 as wide as medially long. Clypeus smooth, sparsely hairy, transverse, ca 2.0 as wide as long, in transverse axis slightly convex, in vertical direction rather straight. Lower margin of clypeus subtruncate, rather narrow, slightly up- curved, with one row of marginal setae, the most lateral 1-2 setae longer and diverging outwards. Mandible rather broad, with upper tooth longer than lower. Malar space short, without furrow, with dense microsculpture, mat. Occipital carina complete, joining hypostomal carina above base of mandible. Antenna with 15 flagellomeres, flagellomeres (2)3-6 each with a small tooth on apical (0.7) part of segment. Subapical flagellomeres elongate, not moniliform.

Mesosoma 1.72 as long as wide, 1.32 as high as wide. Epomia present, rather weak. Mesoscutum smooth, shining, with thick, rather short setae. Notauli impressed only near anterior margin, posteriorly mesocutum with some longitudinal striae. Scuto-scutellar fovea rather smooth. Lateral carinae of scutellum reach to the top, posterior surface with a medial keel. Epicnemial carina strong, complete, reaching anterior edge of mesopleuron, with lower anterior branch reaching front margin. Lower part of mesopleuron with longitudinal striae throughout. Postpectal carina broadly interrupted anterior to mid coxa. Propodeum short, strongly descending posteriorly, anteriorly with deep, u-shaped furrow against hind part of metanotum. Carinae of propodeum high, strong, complete, except areola and basal area joined and costula absent. Petiolar area long, ca 2.0 as long as combined basal area and areola. Propodeal spiracle small, round. Fore tibia with fine setae, without tooth on dorsal margin, as long as fore tarsus. Fore tarsomere 5 (Fig. 11) enlargened, claw with several black teeth, the most apical tooth longer than the others. Mid-tarsomere 5 thin, claw (Fig. 12) with similar but smaller teeth. Hind tibia with inner spur slender, short, ca 0.39 as long as hind tarsomere 1 . Hind tarsus slightly longer (1.07) than hind tibia, hind claw (Fig. 13) long, with one long, blackish teeth basally and 2-3 smaller teeth. Pterostigma ca 3.1 as long as wide, emitting radius at its basal 0.4 . Areolet open. Nervulus slightly postfurcal. Nervellus reclivous, not intercepted. Discoidella absent.

Metasomal tergum $1 \mathrm{ca} 3.2$ as long as wide, with spiracle a little anterior to the middle, in side view its dorsal profile strongly bent, convex about in the middle, glymma absent, ventrolaterally with 4 setae directed anterolaterally. Anterior to spiracle petiolus 1.2 as wide as high. Postpetiolus ca 1.65 as long as wide, with strong lon- 
gitudinal striae. Metasomal tergum 2 smooth, shining, transverse, in dorsal view medially 0.71 as long as wide, shorter laterally, with minute, transverse thyridiae on anterior margin, hind margin strongly convex, with spiracle near hind margin, a crease present in the form of a fine, sharp line between the dorsal tergum and laterotergite anterior and a little below spiracle, laterotergites meeting each other at midline. Tergum 3 large, medially 1.7 as long as tergum 2 , ca 0.83 as long as wide, with no crease, finely punctate laterotergites broadly overlapping each other ventrally. Tergum 4 short, transverse, 0.42 as long as basally wide in dorsal view. Following terga more or less telescoped inside anterior terga. Ovipositor sheath narrow, almost straight, with numerous decumbent hairs, ca 0.6 as long as hind tibia.

Description of male (from Janakkala). Length of fore wing $2.8 \mathrm{~mm}$. Colour as in female, except clypeus, mandibles, palpi, scape, pedicel and flagellomeres 1-2 brownish yellow. Tegula yellowish brown, humeral plate brownish yellow and pterostigma brown.

Head as in female. Antenna with 16 flagellomeres, flagellomeres 3-6 each with a small tooth on apical (0.7) part of segment.

Mesosoma as in female, except mesoscutum posteriorly with $0.05 \mathrm{~mm}$ long keel, scuto-scutellar fovea medially smooth, laterally with 3 keels. Scutellum weakly margined to near apex, posteriorly with weak rugosity. Epicnemial carina not reaching anterior margin of mesopleuron. Fore tarsomere 5 thinner than in female, fore claws with weaker black teeth. Mid- and hind claws with weak teeth basally.

Metasomal tergum 1 as in female. Tergum 2 in dorsal view 0.60 as long as wide, tergum 3 large, 1.64 as long as tergum 2, 0.72 as long as wide. Tergum 4 transverse, mostly inside tergum 3 , following segments telescoped inside terga 34.

Variation. The number of flagellomeres and corresponding length of fore wing (mean and range in $\mathrm{mm}$ ) are as follows:

\section{Flagellomeres,}

female; $13(\mathrm{n}=1)$

$14(\mathrm{n}=8)$

$15(\mathrm{n}=25)$

$16(\mathrm{n}=8)$

male; $14(\mathrm{n}=2)$ fore wing

2.0

$2.47(2.3-2.6)$

$2.66(2.45-2.95)$

$2.99(2.9-3.1)$

$2.23(2.2-2.25)$ $15(n=3)$

$16(n=5)$

$2.57(2.5-2.6)$

$2.71(2.6-2.85)$

Usually areolet open, but in one female from Polvijärvi anterior 0.4 of vein $3 \mathrm{r}-\mathrm{m}$ present in both wings.

Specimens examined (total $42 \% 110^{*}$ ). Holotype female: Finland. Ta: Janakkala, [Grid $27^{\circ} \mathrm{E}$ ] 6758:372, 3.7.1997, leg. V. Vikberg (DAZH). Paratypes: Finland. Ab: Houtskari, Hyppeis, 669:18, 1-15.7.1990, light trap $1 \%$, leg. H. Bruun (RJPC). Sauvo, Karuna, 669:25, Malaise trap, 1.6.-27.6.1998 1우 10.7.-29.7.1998 2우, 18.7.28.7.1999 10 $\sigma^{*}$, leg. R. Jussila (RJPC). Salo, Uskela, 670:28, on Picea abies or Larix sp., 27.6.1948 1 9 , E. K. Lahtinen leg. (ZMUT). Vihti, Siikajärvi, 668:36, 21.6.1964 1 ㅇ leg. V. J. Karvonen; 24.7.1969, light trap, 2 leg. A. Petramaa; July - Aug. 1969, light trap, $1 \sigma^{*}$ leg. A. Petramaa; 16.7.1971, 10 leg. V. J. Karvonen (DAZH). N: Tammisaaren mlk. [now Hanko], Tvärminne, 664:28, 26.6.-1.7.1972 light trap, $1 \sigma^{*}$ leg. Karvonen (DAZH). St: [Vammala], Karkku, Papinsaari, 682:28, 11.7.1952, $1 \sigma^{*}$ leg. W. Hellén (ZMUH). Ta: Janakkala, 6758:372, 5.8.1996 1; 3.7.1997 1o; 10.7 .19971 \%; 15.7.1997 1 우 18.7.1997 3우 20.7.1997 1; 21.7.1997 1우 ; 28.7.1997 2\%; 10.8.19972\%, 25.6.1998 1o, 12.7.1999 1 ㅇ, all leg. V.Vikberg (NHML, VVPC). [Hämeenlinna], Vanaja, 17.7.1958, 19 leg. E. Valkeila (DAZH). Oa: Ilmajoki, 697:27, 6.7.1999 1\%, R. Jussila leg.(RJPC). Tb: Keuruu (labelled Keuru), railway station, 690:37, 25.7.1928, 1 ㅇ leg. W. Hellén (ZMUH). Kb: Joensuu, 694:64, 20.6.1963 1ㅇ, leg. V. Vikberg (VVPC). Polvijärvi, 6961:626, 5.7.1994 1이 leg. M. Koponen (DAZH). Ok (= Kn): Kuhmo, Luhtavaara, 7152:610, bait trap, 11.8.-24.8.1997 10 , leg. M. Kuussaari, H. Lappalainen \& M. Romppanen (KREC). Sweden. Skåne, trap 1, July $19691 \%$, leg. Bo Svensson (AEIG). Bohuslän: NW of Ödsmål, mixed forest, 18-19.8.1979 1 ㅇ, leg. M. Söderlund (ZSSM). LU: Messaure, 6.7.1972 1ㅇ, leg. Karl Müller (AEIG). England. Devon, Brickleigh Vale, 20.6.1960, 1 ㅇ leg. J. F. Perkins (NHML). Oxfordshire, Oxford, June $198010^{\star}$ (C23) 1 우 (C40), July 19801 우 (C15), June $19811 \%$ (C9), leg. Denis Owen (AEIG). Herefordshire, Moccas Park NNR, mature deciduous wood, FI trap, 20.5.-24.5.1992 1우 ; 24.5.-31.5.1992 1웅 3.6.-8.6.1992 1\%; 20.6.-24.6.1992 1\%; all leg. J. Cooter (NMSE). Cambridgeshire, Chippenham Fen, TL 650693, Malaise trap: carr at reedbed edge, 25.6.-5.7.1985 1우, leg. J. Field (NMSE). Norfolk, Santon Downham, TL 818883, Malaise trap: heath with birch and pine, 17.6.25.6.1985 1ㅇ ; 6.7.-20.7.1985 1ㅇ, both leg. J. Field (NMSE). Scotland. Dunbartonshire, Caldarvan, NS 448838, Malaise trap: Betula and Myrica, 8.6.-20.6.1983 $1 \sigma^{*}$, leg. I. C. Christie (NMSE). W. Ross, Rassal NNR, NG 845432, Malaise trap, July 19911 ㅇ, leg. P. W. Brown (NMSE). France. Lot-et. Garonne, Bernac, Malaise trap, 26.6.-30.6.1992 19, leg. R. R. Askew (NMSE).

Distribution. Britain (England, Scotland), Finland, France, and Sweden (all new).

Biology. In southern Finland specimens have been captured from 20 June to 10 August, most specimes in July. In Sweden specimens captured 
on 18 August, in Britain from 20-24 May to 6-20 July. Host unknown. Specimens from Janakkala $\left(2 \sigma^{\circ} 14\right.$ ) $)$ were swept from low herbage and bushes near logs of Pinus and Picea. Conifers were absent from some of the British collecting sites (M. R. Shaw, pers. comm.).

\subsubsection{Astrenis paradoxus (Schmiedeknecht, 1907)}

Mengersenia paradoxa Schmiedeknecht, 1907: 606. Syntypes: Germany, Thüringen, Blankenburg, 3 females. Lectotype female (ZMHB) hereby designated is labelled: 1) a small orange-yellow quadrate label, 2) Coll. Schmiedeknecht, 3) Mengerssenia (sic) paradoxa $\&$ Schmiedek. (handwritten), 4) Typus (red label), 5) Zool. Mus. Berlin., 6) a lectotype label was added by author VV. The micropinned specimen lacks the left flagellum, otherwise it is in good condition.

Another female (ZMHB) similarly labelled but lacking an orange-yellow label does not fit the original description; it is a female of Phrudus defectus Stelfox. One possible syntype of Mengerssenia paradoxa is in coll. Museo Nacional de Ciencias Naturales Madrid (Horstmann 1990), but we did not try to examine it.

The species has been recorded from Germany (Schmiedeknecht 1907, 1910, Hedwig 1939, Hilpert 1989), France (Seyrig 1932, Aubert 1957) and England (Gauld \& Fitton 1980).

Description of female. Lectotype: Length of fore wing $2.45 \mathrm{~mm}$, number of flagellomeres 16 . Syntype females had 17 flagellomeres according to Schmiedeknecht (1907).

Black. Head reddish to yellowish brown, ocellar area infuscate. Mandible brownish yellow, teeth amber red. Palpi brownish yellow. Antenna brown, scape, pedicel and flagellomeres 1-2 brownish yellow. Tegula, humeral plate brownish yellow, pterostigma brown. Legs yellowish brown, coxae infuscate, hind coxa almost black. Hind femur darker brown, infuscate, hind tibia narrowly infuscate at base and apex, hind tarsomere 1 infuscate. Metasoma posterior to segment 1 brownish yellow.

Head in dorsal view 0.63 as long as wide, with temples narrowing behind the eyes, rounded, in anterior view head is 0.87 as high as wide. Vertex and frons smooth, shining, densely hairy, the hairs rather long. Eyes almost glabrous, with some small hairs on lower part, converging slightly ventrad on frons, subparallel on face. Face transverse, 2.0 as wide as medially long, rather smooth, thickly hairy, medially all hairs directed downwards. Clypeus separated from face by a distinct furrow, transverse, 2.6 as wide as high, smooth, in transverse axis slightly convex, in vertical direction rather straight, clypeal margin medially almost truncate, laterally rounded, with one row of marginal setae. Upper tooth of mandible longer than lower. Occipital carina complete, joining hypostomal carina distinctly above mandible. Maxillary palpi with 5 segments, labial palpi with 3 segments. Antenna with basal 6 flagellomeres distinctly elongate, subapical flagellomeres nearly quadrate, with rounded edges, moniliform. Flagellomeres 3-6 each with a small tooth on distal (0.6-0.7) part of segment.

Mesosoma 1.77 as long as wide, 1.26 as high as wide. Epomia rather long, continuing backwards and reaching hind margin of pronotum as striae. Mesoscutum smooth, shining, with rather long hairs all over, notauli impressed only near anterior margin. Scuto-scutellar fovea smooth. Lateral carinae of scutellum reach to the top, posterior slope of scutellum with a medial carina. Epicnemial carina not reaching anterior margin of mesopleuron, but lower anterior branch reaching anterior margin. Mesepisternum smooth, largely glabrous, the lower part longitudinally striate. Metapleuron and hind coxa with wrinkled to rugose sculpture. Structure and carination of propodeum similar to that of A. nigrifacies. Fore tibia with fine setae, lacking a tooth on apical dorsal margin, as long as fore tarsus. Claws of fore tarsus with many subequal teeth. Hind femur 5.1 as long as high. Hind tibia slightly (1.02) longer than hind tarsus, with inner spur slender and short, 0.38 as long as hind tarsomere 1. Hind claws slightly longer than arolium, basally with 4-5 subequal teeth. Pterostigma 3.0 as long as wide, the radius leaving from the middle. Nervulus interstitial. Nervellus strongly reclivous, not broken, discoidella absent.

Metasomal tergum 14.2 as long as wide, with spiracle slightly before middle (0.49), its dorsal profile convex, strongly bent in the middle. Petiolus 2.7 as long as wide, posteriorly 0.91 as high as wide. Postpetiolus 2.2 as long as wide. Tergum 1 ventrolaterally with 5 setae directed anterola- 
terally. Tergum 2 medially 0.73 as long as postpetiolus, with apical margin convex, shorter laterally, spiracle near posterior margin, thyridiae and crease absent. Tergum 3 medially 1.35 as long as postpetiolus, it is the broadest tergum and about as wide as long. Tergum 4 transverse, the following terga telescoped inside terga 3-4. Ovipositor sheath narrow, straight, dark brown, 0.3 as long as hind tibia.

Description of male. Only one specimen studied: length of fore wing $2.8 \mathrm{~mm}$, antenna with 17 flagellomeres.

Colour similar to female, except face, clypeus, lower gena, scape, pedicel, flagellomeres 1-3, tegula and humeral plate paler, almost yellow. Fore coxa and base of hind tibia not infuscate. Fore claw with teeth black as in female, but midand hind claws have teeth brownish.

Head as in female, except antenna longer with subapical flagellomeres slightly elongate, flagellum with numerous short, curved, upright setae, flagellomeres 3-6 each with a small tooth on distal half, their size becoming smaller distally.

Mesosoma as in female, except mesoscutum with less numerous hairs, with small glabrous areas on lateral lobes, upper end of epicnemial carina connected by striae with anterior margin of mesopleuron. Pterostigma 2.8 as long as wide, emitting radius before middle (0.45). Nervulus interstitial or weakly postfurcal. Nervellus slightly reclivous, rounded, without ramus.

Metasomal segment 1 as in female. Tergum 2 as in female, 1.3 as wide as medially long, 0.62 as long as tergum 3 . Tergum 3 broadest of all, 1.17 as wide as medially long, tergum 4 transverse, for most part telescoped inside tergum 3 . Following segments telescoped inside terga 3-4.

Variation. All three females examined have 16 flagellomeres, and the mean length of fore wing $(\mathrm{n}=3)$ is $2.37 \mathrm{~mm}$ (range 2.3-2.45). Upper medial frons and occiput can be infuscate. Nervulus may be slightly postfurcal. In English females the nervellus is weakly reclivous, near its middle with a short ramus, discoidella otherwise hardly visible.

Specimens examined ( 3 \% $\left.10^{*}\right)$. Sweden. Sk: Höör distr., 16.6.1938 $1 \sigma^{*}$, leg. D. M. S. P. \& J. F. P. (NHML). England, Cambridgeshire, Chippenham Fen, TL 650693, Malaise trap: carr at reedbed edge, 29.6.-9.7.1984 1\%; 27.8.-27.9.1984 1 ㅇ, both leg. J. Ficld (NMSE). Germany, Thüringen, Blankenburg, 1 (the lectotype), leg. O.
Schmiedeknecht (ZMHB).

Distribution. Britain (England), France, Germany, and Sweden (new).

Biology. Only a few specimens captured, but the flight period is obviously long, at least from 16 June to the end of August. Host unknown.

\subsubsection{Astrenis brunneofacies Vikberg sp. nov. (Figs 4, 14)}

Description of female. Holotype: Length of body $2.5 \mathrm{~mm}$, of fore wing $2.65 \mathrm{~mm}$. Body black. Face dark brown, clypeus and mandible yellowish brown. Palpi, scape, pedicel and flagellomeres 12(3) brownish yellow, flagellum otherwise dark brown. Tegula and humeral plate brownish yellow, pterostigma pale brown. Legs brownish yellow, base of hind coxa brownish black, hind tarsomeres 1-2 slightly infuscate. Metasomal tergum 2 pale brown, terga 3-4 dark brown.

Head in dorsal view 0.76 as long as wide, with temples narrowing behind eyes, rounded, in anterior view head is 0.92 as high as wide. Vertex and frons smooth, shining, with thick and long pubescence all over. Eyes almost glabrous, with some small hairs on lower part, slightly converging ventrad on frons, subparallel on face. Face transverse, 0.6 as high as wide, rather smooth, thickly hairy, all medial hairs directed downwards. Clypeus separate from face by a distinct groove, transverse, 2.6 as wide as high, smooth, in transverse axis slightly convex, in vertical direction straight, clypeal margin medially truncate, laterally rounded, anteriorly with a row of brownish spinulae, with one row of marginal setae. Clypeal foveae narrow, slitlike. Mandible rather broad, with upper tooth longer than lower. Occipital carina complete, joining high, lamellate hypostomal carina above basal part of mandible. Basal 5-6 flagellomeres elongate, subapical flagellomeres about as long as wide, with rounded edges, submoniliform. Flagellomeres 3-7 each with a small tooth on distal (0.7) part of segment.

Mesosoma 1.86 as long as wide, 1.41 as high as wide. Epomia rather weak. Mesoscutum smooth, shining, with rather long hairs all over, notauli impressed only near anterior margin. Scuto-scutellar fovea smooth. Epicnemial carina not reaching anterior margin of mesopleurum. 
Mesepisternum with strong longitudinal striae on lower part. Metapleuron and hind coxa with rather fine granulate microsculpture, matt. Submetapleural carina anteriorly expanded, lobe-like. Structure and carination of propodeum similar to those of A. nigrifacies. Fore tibia with fine setae, lacking tooth on apical dorsal margin, as long as fore tarsus. Claws of fore tarsus with many subequal teeth. Hind tibia slightly (1.06) longer than hind tarsus, with inner spur slender and short, 0.36 as long as hind tarsomere 1. Claws of hind tarsus shorter than arolium, with several teeth. Pterostigma 4.0 as long as wide, emitting radius from basal 0.43 .

Metasomal tergum 13.8 as long as wide, with spiracle ca in the middle, its dorsal profile convex, strongly bent in the middle. Petiolus 2.0 as long as wide, anterior to spiracle 0.76 as high as wide. Postpetiolus 2.0 as long as wide. Tergum 2 medially 0.55 as long as tergum 3 , apical margin convex, with spiracle near hind margin, thyridiae absent, without any crease. Tergum 4 medially slightly longer than tergum 2 . Ovipositor sheath narrow, straight, 0.31 as long as hind tibia.

Description of male (from Konnevesi). Length of fore wing $2.65 \mathrm{~mm}$. Antenna with 16 flagellomeres.

Black. Face yellowish brown, clypeus, mandibles except amber red teeth, gena around base of mandible and palpi brownish yellow. Antenna dark brown, scape, pedicel and flagellomeres 1-3 brownish yellow. Tegula yellowish brown, humeral plate brownish yellow. Legs brownish yellow, hind coxa infuscate basally, apex of hind tibia narrowly infuscate, hind tarsus slightly infuscate, except tarsomere 4.

Head ca 0.67 as long as wide in dorsal view, temples almost parallel immediately behind eyes, then converging, rounded, in anterior view 0.86 as high as wide. Upper frons with a glabrous area medially, temples glabrous behind eyes in lateral view. Clypeal margin convex, anteriorly with a row of brownish spinulae.

Epomia long, continuing as carina backwards and reaching hind margin of pronotum as three fine striae. Mesoscutum sparsely hairy, with glabrous areas on mid- and lateral lobes. Epicnemial carina not reaching anterior margin of mesopleuron, but connected with it by striae, lower anterior branch reaching anterior margin of mesopleu- ron.

Metasomal tergum 14.35 as long as apically wide, with spiracle slightly behind $(0.53)$ the middle. Postpetiolus 2.3 as long as wide. Tergum 20.8 as long as postpetiolus, 0.88 as long as wide. Tergum 31.34 as long as postpetiolus, 1.15 as long as wide. Metasoma posterior to segment 1 1.4 as long as tergum $1,2.3$ as long as wide in dorsal view, slightly higher than wide.

Variation. The number of flagellomeres and corresponding length of fore wing (mean and range in $\mathrm{mm}$ ) are as follows:

$\begin{array}{lll} & \text { Flagellomeres, } & \text { fore wing } \\ \text { female; } & 15(\mathrm{n}=3) & 2.60(2.6-2.6) \\ & 16(\mathrm{n}=13) & 2.55(2.35-2.7) \\ \text { male; } & 15(\mathrm{n}=3) & 2.42(2.3-2.5) \\ & 16(\mathrm{n}=8) & 2.55(2.3-2.7)\end{array}$

Specimens examined $\left(15 \% 11 \sigma^{*}\right)$. Holotype female: Finland (= Suomi). Sa (=ES): Mikkelin mlk., [Grid 27 $\left.{ }^{\circ} \mathrm{E}\right]$ 6830:501, 24.6.1988 leg. M. Koponen (DAZH). Paratypes: Finland. Ab: Vihti, Siikajärvi, 668:36, light trap, 6.7.1963 1 ơ ; 18.7.1964 1\%, both leg. V. J. Karvonen (DAZH). N: Nurmijärvi, 6715:376, 28.6.1980, 1 đ leg. M. Koponen (DAZH). Ta: Janakkala, 6755:369, 15.7.1978 1ㅇ; 6758:372, 27.7.19991ㅇ, 7.8.1999 1웅, leg. V. Vikberg (VVPC). Nastola, 6774:436, 17.8.1980, $10^{*}$ leg. M. Koponen (DAZH). Tampere, 682:32, 29.8.1964, 10 leg. V. Vikberg (VVPC). Oa: Ilmajoki, 6965:270, 5.7.1999 10 ; 6971:260, 7.7.1999 10, M. Koponen leg. (DAZH). Tb: Konnevesi, 6945:466, 19.8.1986, 1 ơ leg. M. Koponen (DAZH). Ok $(=\mathrm{Kn})$ : Kuhmo, Särkijärvi 7111:622, window trap, 18.7.29.7.1997 1 9 , leg. M. Kuussaari, H. Lappalainen \& M. Romppanen (KREC). Sweden. Skåne, trap 1, July 1969 10 ${ }^{*}$, leg. Bo Svensson (AEIG). LU: Messaure, 4.8.1972 1\%, leg. Karl Müller (AEIG). England. Shropshire, Wenlock edge, 24.6.1958, 1 đ leg. J. F. Perkins (NHML). Scotland. Dunbartonshire, Caldarvan, NS 450836, Malaise trap: mixed wood by pond, 18.6.-27.6.1983, 1 \% leg. I. C. Christie (NMSE). Inverness, Loch Garten, Malaise trap, June-Aug. 19811 \%; Aug. 19811 \%, both leg. J. A. Owen (NMSE). W. Ross, Beinn Eighe NNR, NH 0064, Malaise trap: native pine, Aug, 1988 2 ; Aug. 198919 , all leg. I. MacGowan (NMSE). Germany. Bayern: Kochel, 650-1150 m, 12.7.1985 10*, leg. Haeselbarth (ZSSM). Italy. Südtirol: St. Peter/Ahrntal, $1275 \mathrm{~m}$, 27.8.1967 19, leg. Haeselbarth (ZSSM). Vicenza: Piovene Mte., Summano, 900-1300 m, 3.7.1985 1 क 1 \% , leg. Haeselbarth (ZSSM).

Distribution. Britain (England, Scotland), Finland, Germany, Italy, and Sweden (all new).

Biology. In southern Finland specimens have been captured from 24 June to 29 August; several specimens in Finland were captured near pine logs and wood piles. Specimens from Britain are from the same period. Host unknown. 


\subsection{Phrudus Förster, 1869}

Phrudus Förster, 1869: 196. Type species: Phrudus monilicornis Bridgman, the first included species in Dalla Torre 1901: 329 (by monotypy).

Phrudus Bridgman, 1886:361. Type species: Phrudus monilicornis Bridgman, by monotypy.

Ktenostilpnus Strobl, 1901:256. Type species: Ktenostilpnus aequearticulatus Strobl, by monotypy.

Vendolus Roman, 1914: 35. Type species: Vendolus stilpninus Roman, by monotypy.

Roman (1925: 32) synonymized Phrudus Bridgman, Ktenostilpnus and Vendolus and placed the only species, $P$. monilicornis, known to him near Demophorus Thomson in Cremastina.

The genus Phrudus is characterized in the key.

The distribution of the genus is Holarctic and Oriental. From the Nearctic region the following species which belong to Phrudus s. str. have been described: Phrudus dakota Cushman, 1927 and P. exarealatus Cushman, 1927 (Cushman 1927, Carlson 1979). From Taiwan four species: $P$. angustus, $P$. linorum, $P$. longius and $P$. montanus were described by Chiu in Chiu \& Wong (1987).

Four European species form two species groups: the monilicornis-group (only monilicornis) and the defectus-group (defectus, compressus and badensis). The species groups are distinguished from each other in the key.

\subsubsection{Phrudus monilicornis (Bridgman, 1886) (Figs 5, 6, 15, 16)}

Phrudus monilicornis Bridgman, 1886: 361. Lectotype female: England, Surrey, Shere (Castle Museum, Norwich) (Fitton 1976: 318).

Ktenostilpnus aequearticulatus Strob1, 1901: 256. Syntypes: [Austria, Steiermark], Natterriegel, in prealpine meadow, on 26 July, [year not given] one female, and Götzenberg in Siebenbürgen[= Romania, Transilvania] on 29 July, [year not given] one male. Lectotype: the male was designated by Townes 1967: 59 as $K$. aequiarticulatus (!). The male (coll. NMGS) was examined, it is labelled "Kt. aequeart.,29/7 $\sigma^{\pi}$, Transsylv. Strobl" and a red lectotype label was added. The female syntype was also examined, it is labelled "Styriae alp., Strobl" and on a separate pin "Ktenostilpnus aequearticulatus m. \&, 26/7 90, Styriae alp., Strobl", and a red paralectotype label was added.

Vendolus stilpninus Roman, 1914: 38. Holotype female: Sweden, Upsala, near observatorium, beginning of August, 1905, leg. A. Roman (NHRS). According to information from Dr. L. $-\AA$. Janzon, in November 1997 the type was found to have been eaten by a dermestid so that only the wings are left on a small part of body.

This is the largest and best known European species. In addition to the original descriptions mentioned above it has been recorded from southern Sweden (Thomson 1888), from Britain (Morley 1911, Carr 1924 [? continental, see 3.6.1], Gauld \& Fitton 1980), from Germany (Lange 1898, Schmiedeknecht 1912, Habermehl 1925, Pfankuch 1935, Hedwig 1940, 1950, 1959, Starke 1956, Aerts 1957, Hilpert 1987b, 1987c), from France (Maneval 1935, Aubert 1957), from southern Finland by Hellén (1946), from Bulgaria by Kolarov (1984), and from Bohemia (now part of the Czech Republic) by Šedivý (1989). Phrudus monilicornis has been recorded also from Taiwan in the Oriental region (Chiu \& Wong 1987). Good figures of a female [from Austria, see specimens examined] were presented in Townes (1971: fig. 28), these were later used by Kasparyan (1981) and Wahl (1993: Fig. 178 of Phrudus). The species was keyed and figured from Britain by Gauld \& Fitton (1980).

Description of female. Body black. Mandible yellowish brown, with teeth amber red. Palpi brownish yellow. Antenna brown, scape and pedicel yellowish brown. Tegula brown, humeral plate yellowish. Venation and pterostigma dark brown, anal vein pale. Legs yellowish brown, coxae infuscate, hind coxa black, tarsomeres 5 infuscate, pecten of claws black.

Head ca 0.76 as long as wide in dorsal view, temples subparallel behind eyes, in anterior view head ca 0.95 as high as wide. Vertex and frons smooth, shining, sparsely setose, upper frons with large glabrous areas. POL/OOL 0.54. Face ca 1.75 as wide as medially long, with fine transverse microsculpture, thickly setose, medially the uppermost setae directed upwards, below that forward and the anterior setae are directed toward clypeus. Clypeus very transverse, ca 3.1 as wide as high, rather vaguely separated from face, clypeal foveae small, oval, not impressed. Clypeus slightly convex in transverse axis, smooth, sparsely punctured, with more numerous and larger punctures near lower margin, a little impressed medially, lower margin sharp. Cheek 0.5 as long as basal width of mandible. Gena smooth, hairy, occipital carina complete, joining hypostomal carina above base of mandi- 
ble. Antenna short, flagellomeres about as long as wide, subapical ones with rounded bases, moniliform, the most apical elongate. Flagellomeres 4-8 near their base each with a hook-like small spine (Fig. 5).

Mesosoma 1.79 as long as wide, 1.13 as high as wide. Epomia weak. Mesoscutum smooth, thickly covered with short setae, the lateral lobes having longitudinal glabrous areas. Notauli not impressed. Scutellum margined only near scutoscutellar fovea. Epicnemial carina not reaching anterior margin of mesopleuron, ending opposite of lower 0.25 of hind margin of pronotum, an anterior branch reaching anterior margin just above the lower hind corner of pronotum. Mesepisternum smooth, shining, sparsely punctate, speculum smooth, glabrous. Postpectal carina broadly interrupted anterior to mid-coxa. Propodeum with almost complete areolation, horizontal part short. Areola transverse, costula near hind margin. Spiracle rather large, roundish, with broad side walls. Fore femur robust. Fore tibia with fine setae, without a tooth on its apical dorsal margin, 1.24 as long as fore tarsus, fore tarsomeres 2-4 transverse, 5 enlarged. Claws of fore and mid-legs with strong pecten to apex, claws of hind leg with less strong pecten (Fig. 16), leaving the brown apex of the claw without teeth. Hind femur 2.94 as long as high, hind tibia as long as hind tarsus, inner spur 0.46 as long as hind tarsomere 1. Pterostigma 2.5 as long as wide, emitting radius near the middle (0.48-0.51). Areolet closed. Nervulus postfurcal. Nervellus straight.

Metasoma posterior to segment 1 depressed, 2.0 as long as wide in dorsal view. Tergum 11.92 as long as wide, spiracle in anterior half $(0.40)$. Petiolus 1.23 as long as apically wide, ca 0.72 as high as wide anterior to spiracle, no glymma. Postpetiolus 1.16 as long as wide. Tergum 20.61 as long as apically wide in dorsal view, with small transverse thyridia near anterior margin, spiracle about in the middle, fine crease entire along lateral side of tergum. Tergum 3 the broadest, 1.24 as long as tergum 2, 0.68 as long as broad. Ovipositor sheath narrow, slightly upcurved, 0.30 as long as hind tibia. Ovipositor 0.82 as long as hind tibia, base broad, apically narrow, slightly upcurved, without nodus.
Description of male. Colour similar to female, sometimes scape and pedicel black and femora, especially hind femur, infuscate. Head in dorsal view $0.63-0.68$ as long as wide, with temples converging (small specimens) or diverging behind eyes in large specimens, 0.90 as high as wide in anterior view. Antenna longer, all flagellomeres elongate, flagellomeres 4-8 each with a long, curved spine near basal margin (Fig. 6). Clypeal margin medially thick, blunt, only near lateral corners sharper.

Mesosoma: all claws, including hind claws, strongly pectinate to apex (Fig. 15).

Metasoma posterior to segment 1 depressed, ovoid, 2.6 as long as wide. Tergum 12.4 as long as apically wide, with spiracles anterior $(0.42)$ to middle, postpetiolus $1.21-1.36$ as long as wide. Tergum $20.62-0.72$ as long as wide, tergum 3 $0.68-0.74$ as long as wide in dorsal view.

Variation. The number of flagellomeres and corresponding length of fore wing (mean and range in $\mathrm{mm}$ ) are as follows:

$\begin{array}{lll} & \text { Flagellomeres, } & \text { fore wing } \\ \text { female; } & 14(\mathrm{n}=1) & 2.35 \\ & 15(\mathrm{n}=12) & 2.76(2.6-3.1) \\ & 16(\mathrm{n}=32) & 3.01(2.6-3.5) \\ & 17(\mathrm{n}=17) & 3.18(2.85-3.6) \\ \text { male; } & 18(\mathrm{n}=1) & 3.5 \\ & 16(\mathrm{n}=18) & 2.68(2.4-3.0) \\ & 17(\mathrm{n}=53) & 2.91(2.5-3.4) \\ & 18(\mathrm{n}=26) & 3.05(2.8-3.65) \\ & 19(\mathrm{n}=5) & 3.55(3.4-3.7)\end{array}$

Specimens examined (total 61 o $103 \sigma^{*}$ ). Finland (18 क 48ð ). Al: Eckerö, Storby, Grid $27^{\circ} \mathrm{E} 670: 08,19.8 .1939$ $1 \%$, leg. W. Hellén (ZMUH). Mariehamn, 668:10, 21.7.1946 1 , leg. W. Hellén (ZMUH). Lemland, 667:11 (“665:45”), 6.8.1978 16"; 667:11, 8.7.1984 1 đ, leg. R. Jussila (KHUW, RJPC). Saltvik, Kvarnbo, 670:11, 11.7.1944 10, leg. W. Hellén (ZMUH). Ab: Korpo, Korpoström, 6678:199, light trap 9.8.-19.8.1992 19, leg. M. Nieminen (VVPC). Nauvo, Seili, 669:22, 18.7.1978 10 leg. M. Koponen (DAZH). Naantali, 671:22, light trap, 23.7.1965 1\%, leg. V. J. Karvonen (DAZH). Nystad = Uusikaupunki, 675:19, 17.8.1914 $1 \sigma^{*}$ leg. W. Hellén (ZMUH). Dragsfjärd, Kärra, 667:24, 19.8.1952 1우, leg. W. Hellén (ZMUH). Sauvo, Karuna, 669:25, 12.7.1967 $1 \sigma^{\circ}$, leg. R. Jussila (RJPC). Lohja (Lojo), $1 \sigma^{*}$; Isokorvenlampi, 669:34, 18.8.1949 20, leg. W. Hellén (RJPC, ZMUH). Vihti, 670:35, 5.8.1962 10, leg. V. J. Karvonen (RJPC). Vihti, Siikajärvi, 668:36, 19.7.1964 1 ; light trap 27.8.1965, 1 ; ; 5.8.1967 1 $;$; 30.7 .19691 o , leg. V. J. Karvonen (DAZH). Karkkila (labelled Pyhäjärvi), $671: 34,26.7 .19591 \sigma^{*} ; 31.7 .19591 \sigma^{*} ; 25.7 .19601 \sigma^{*}$, 
leg. V. Vikberg (VVPC). N: Kirkkonummi, 667:35, 5.8.1962 1 đ, leg. V. J. Karvonen; 6654:355, 23.7.1991 1 ㅇ; 24.7.1991 1 đँ, leg. M. Koponen (DAZH). Nurmijärvi, Kiljava, 671:37, 14.7.1983 12.35, leg. V. Vikberg (VVPC); 6707:382, 26.8.1993 1 o', leg. M. Koponen (DAZH). Helsinki ("H:fors"), 667:38, 1 б", leg. W. Hellén (ZMUH); 6682:382, 20.7.1977 1 के, leg. M. Koponen (DAZH). Ka: Kotka, Kymi, 6718:494, 31.7.1977 $1 \sigma^{*}$, leg. M. Koponen (DAZH). Virolahti, 671:53, 27.7.1975 $1 \sigma^{7} ; 8.8 .19751 \sigma^{\star *} ; 22.7 .19761 \sigma^{\star}$, leg. R. Jussila (RJPC). St: Pori, Reposaari, 684:20, 5.8.1970 1 \&, leg. V. Lauro (RJPC). Huittinen, 679:27, 27.7.1991 1 б, leg. R. Jussila

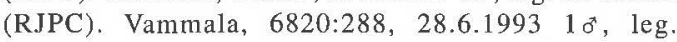
M.Koponen (DAZH). Ta: Riihimäki, 6736:379, 15.8.1997 $1 \%$, leg. V. Vikberg (VVPC). Janakkala, 6755:368, 30.7 .19981 o $3 ; 6755: 369,21.7 .19991$ 우 $6758: 372$, 6.8.1994 1\%; 6760:369, 15.8.1998 1우 ; Suurisuo, 676:38, 14.7.1984 $1 \mathrm{~d}$, leg. V. Vikberg (VVPC). Tampere, 682:32, 28.7.1964 10; 11.8.1964 1\%, leg. V. Vikberg (VVPC). Sa: Ristiina, 6826:501, 14.8.1976 1\%; 6826:502, 8.7.1979 1o; 6821:514, 23.7.1994 1 ơ, leg. M. Koponen (DAZH). Mikkelin mlk., 6830:501, 18.7.1987 1 శే, leg. M. Koponen (DAZH). Pertunmaa, 6809:473, 2.7.1995 $1 \sigma^{*}$, leg. V. Vikberg (VVPC). Kl: Parikkala, Laurila (in Surumäki), 683:63, 7.7.1940 1 $\sigma^{*} ; 14.7 .19451$ \%; ad lucem 11.7.1960 $1 \%$, leg. W. Hellén (RJPC, ZMUH). Oa: Vaasa, 700:22, 5.7.1980 20 $0^{*}$, leg. R. Jussila (RJPC). Ylihärmä, 7011:287, 13.7.1980 $2 \sigma^{*}$, leg. M. Koponen (DAZH). Tb: Keuruu, 690:37, saw mill, 26.7.1928 16, leg. W. Hellén (ZMUH). Uurainen, 6933:432, 14.7.1995 10 , leg. M. Koponen (DAZH). Sb: Joroinen, 690:54, 9.8.1982 $1 \mathrm{o}^{*}$, leg. Y. Zhongqi (DAZH). Kb: Liperi, 6950:622, sweeping lower vegetation under pines, 4.8.1993 20 ${ }^{\text {}}$, leg. M. Koponen (DAZH). Joensuu, 694:64, 6.8.1963 1o; 22.8.1963 1o , leg. V. Vikberg (VVPC). Om: Uusikaarlepyy, 7054:278, 22.7.1980 1 ot, leg. M. Koponen (DAZH). Haapavesi, 7116:423, 9.7.1995 10", leg. M. Koponen (DAZH). Russia, Leningrad region: Kamushki, $40 \mathrm{~km} \mathrm{~S}$ of Leningrad, 1.7.1972 19; KobralovoSemrino, 40-44 km S of Leningrad, 22.7.1972 10, leg. Kasparyan (RJPC, ZISP). Yaroslavl oblast, Berditsyno, 24.7.1994 1o, leg. A. Yakovlev (ZISP). Smolenskaya oblast, National park "Smolenskoye poozerye", 11.6.1993 $1 \mathrm{\delta}^{\star}$, leg. Kasparyan (ZISP). Volgograd oblast, okr. Uryupinsk, Kotovskoe, Dubrava, 15.7.1977 1 , leg. Kasparyan (ZISP). Karatsayevo-Tserkesskaya AO., Teberdinskiy zapovednik, g. M. Chatinara, chv., 14.7.1976 $10^{*}$, leg. Kasparyan (ZISP). Sweden, Ljungby, $150 \mathrm{~m}$, 17.8.1958 1우, leg. David Townes (AEIG). SK: Sc.= Scania, $10^{*}$, leg. Bhn.= Boheman (NHRS). Dalby, 10.8.1938 1 б, leg. D. M. S. P. \& J. F. P. (NHML). Kivik, 19.7.1938 19, leg. D. M. S. P. \& J. F. P. (NHML). Skåne, trap 4, August $19691 \%$, leg. Bo Svensson (AEIG). SM: Sm. $=$ Småland, $7 \sigma^{*}$, leg. Boheman (NHRS). SÖ: Mörkö, 7.7.1977 $10^{\star}$, leg. R. Jussila (RJPC). UP: Hlm.= Holmia= Stockholm area, $1 \sigma^{\star}$, leg. Boheman (NHRS). Lp.m.= Lapponia meridionalis, $1 \sigma^{*}$, leg. Boheman (NHRS). England, Devon, Torquay, 15.6.1960 10, leg. J. R. Vockeroth (CNCO). Surrey, Dorking, 11.7.1964 10, leg. H. \& M. Townes (AEIG). Kent, Eynsford, 18.7.1937 1 $\delta^{\text {* }}$, leg. G. Nixon (NHML). Oxfordshire, Oxford, July 198010 (C12), August 19801 ㅇ (C15), August 19811 (C15), leg. Denis Owen (AEIG). Frilford Heath, SU 442986, Malaise trap 18.6.-12.7.1991, 1 우 leg. K. Porter (NMSE). Northamptonshire, Spratton, Malaise trap July 1975, 1 우 leg. Gauld (NHML). Cambridgeshire, Chippenham Fen, TL 650693, Malaise trap: carr at reedbed edge, 1.8.15.8.1984 1 9 , leg. J. Field (NMSE). Gog \& Magog Hills, 29.7.1937 $1 \sigma^{*}$, leg. R. L. E. Ford (NHML). Norfolk, Santon Downham, TL 818883 , Malaise trap: heath with birch and pine, 30.7.-11.8.1985 1\%, leg. J. Field (NMSE). Leicestershire, Leicester, June $197310^{*}$, leg. Jennifer Owen (AEIG). Wales, Monmouthshire, Trelleck Beacons, 10.6.1936 $1 \sigma^{*}$, leg. E. B. B. \& J. F. P. (NHML). Pembrokeshire, Mynachlog-ddu, 23.6.1977 19, leg. Noyes \& Bouček (NHML). Scotland, Dunbartonshire, Caldarvan, NS 448838, Malaise trap: Betula/Myrica, 1.8.-17.8.1983 10 , leg. I. C. Christie (NMSE). Inverness, Aviemore, 5.8.1946 1ㅇ, leg. P. Harwood (NHML). Creag Meagaidh NNR, Blanket bog, $375 \mathrm{~m}$, NN 416833, yellow bowl 23.7.-7.8.1988 10, leg. D. Horsfield (NMSE). W. Ross, Beinn Eighe NNR, NH 0064, Malaise trap: native pine,

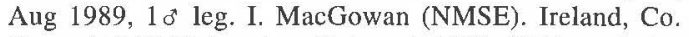
Kerry, 7.8.1940 I o , leg. Beirne (AEIG). Kildare, Leixlip, Rye water, 12.7.1942 $1 \sigma^{\text {* }}$, leg. A. W. Stelfox (NHML). Netherlands, Gelderland: Ede, 21.9.-8.10.1971 1 \%, leg. van Rossem (NNML). Germany, Bayern: Schliersee, 700$1100 \mathrm{~m}, 28.7 .19581$ ㅇ, $750 \mathrm{~m}, 29.7 .19581$ \%, leg. David Townes (AEIG). Ettal, 800-900 m, 29.6.1986 $1 o^{*}$; Flintsbach Inn., 550 m, 13.8.1968 1; Gauting Frohnloch, 29.7.1979 1우 Harthausen bei München, 25.8.1968 1\%; Walchensee, $800 \mathrm{~m}, 6.8 .19811$ \%; Wessling, 7.8 .1972 $1 \%$, leg. E. Haeselbarth (ZSSM). Hessen: Eberschütz, 6.8.1967 1영 Ziegenhagen, 13.8.1966 1ㅇ, leg. E. Haeselbarth (ZSSM). Niedersachsen: Bramwald, 30.7.1967 10; Hedemünden, 10.7.1967 20, leg. E. Haeselbarth (ZSSM). Nordrhein-Westfalen: [near Aachen], $1 \sigma^{*}$ labelled "Phrudus femoralis o'!? m." [metasoma missing], coll. A. Förster (ZSSM). Thüringen: [Bad] Blankenburg, $1 \%$, from coll. E. Bauer (ZSSM), $2 \sigma^{\star}$, coll. Schmiedeknecht (CNCO). Sachsen: Leipzig, 21.8.1898 10, leg. Krieger (ZMHB); Bautzen, 9.8.1896 20, 21.8.1896 1ㅇ, leg. Krieger (ZMHB); Rochlitz[?], 13.8.1888 1ㅇ, 18.8.1888 10, leg. Krieger? (ZMHB); Rü sg ?, 12.8.1892 20*, leg. Krieger? (ZMHB), Czech Republic, Bohemia, Kytin, July 1958 $1 \delta^{\star}$, leg. J. Macek (AEIG). Austria, Kärnten: Ferlach, Drau-Auen, 31.7.1965 $1 \% 1 \%$, leg. K. Horstmann (KHUW). Salzburg: Sbg=?Salzburg, 20.7.1982 1\%, 22.8.1982 1 \% ; Hetzenbichl- St. Johann im Pongau, Bombus agrorum - Nest, 22.8.1985 1\%; Seitling, 19.9.1981 1 ; Thuje Weg, 24.9.1981 1 ㅇ, leg. ?Si (ZSSM). Tirol: Scheffau, $800 \mathrm{~m}, 25.7 .19581 \sigma^{\star}, 26.7 .19581$ o with yellow label: Generic drawing, leg. David Townes (AEIG). Steiermark: Natterriegel, 26.7.1890 1 \% (the paralectotype of $K t$. aequearticulatus), leg. G. Strobl; Admont, 2.7.?year $1 \%, 1.8$.?year 1\%, 26.8.?year 3\%, leg. G. Strobl (NMGS). Switzerland, Bern, Grindelwald, Aug 19371 \%, leg. G. Nixon (NHML). Graubünden: S-charl Clemgiatal, 1900-2000 m, 12.8.1973 1 \% 1 \%; Sent Surains u. Val Gronda, $1500 \mathrm{~m}, 30.7 .19731 \mathrm{~s}$; Tarasp Avrona, $1450 \mathrm{~m}$, Erica-Pinus mugo meadow, 2.8.1973 1 o; $^{*}$ Tarasp Lai Nair, $1550 \mathrm{~m}, 11.8 .19731$ \%, leg. E. Haeselbarth (ZSSM). Italy, Trentino-Alto Adige: BZ, Feldthurns, $1200 \mathrm{~m}$, 11.9.1978 19; Campi, Riva s. Garda, 1000 m, 7.7.1966 
19; Riva s. Garda, 500 m, 3.7.1966 1 8; Tremalzo, Judik. Voralpen, $1300 \mathrm{~m}, 9.7 .19661 \mathrm{o}^{\text {* }}$, leg. E. Haeselbarth (ZSSM). Partschins, S-Tirol, 800 m, 31.8.1967 1 ; St. Peter, Ahrntal, S-Tirol, 1300-1325 m, 25.8.1967 $1 \mathrm{o}^{\text {7 }}$, 28.8.1967 2o ; Walchsee, $800 \mathrm{~m}, 4.6 .19681 \sigma^{\pi}$, leg. E. Haeselbarth (ZSSM). Verona, Malcesine, Bosco ceduo, 500-1300 m, 18.6.1976 10, leg. E. Haeselbarth (ZSSM). Romania, Transilvania, 10 (the lectotype of $K$. aequearticulatus), leg. G. Strobl (NMGS). Ukraine, Ivano-Frankovskaya oblast, $10 \mathrm{~km} \mathrm{~N}$ of Vorochta, Picea- wood, 900 m, 23.7.1989 1 ㅇ, leg. Kasparyan (ZISP). Zakarpatskaya oblast, Tyatsev, 6.8.1989 1 \%, leg. Kasparyan (ZISP). Asia. Kirghizia, Km Toktogula r. Tsytskan, 27.7.1982 1 q, leg. Belokobylskiy (ZISP). This extralimital female has only 14 flagellomeres and the length of the fore wing is 2.65 mm. Taiwan. Meifeng, $2150 \mathrm{~m}, 29.5 .19831$ ㅇ, leg. Henry Townes (AEIG). This extralimital female has 18 flagellomeres and the length of the fore wing is $3.8 \mathrm{~mm}$.

Note 1. Five females from Austria, Salzburg area, in ZSSM are not properly labelled (handwritten labels contain partly shorthand notes), all have wings broken and mesosoma covered with honey, apparently honey of Bombus spp. was used as bait in some kind of trap, because handwritten labels bear one or another of the following words: “ B. hortorum Mehlbeere”, "lapid”, "B. agr.", " $B$. argillaceus", including one specimen labelled "B. agrorum-nest". This raises the possibility that Phrudus monilicornis has something to do with nests of Bombus spp. Earlier Maneval (1935) has recorded $P$. monilicornis from the nest of Bombus agrorum in Tence in France. One further female with wings broken near their base was taken from Bombus lapid[arius] nest debris on 11.9.1905 , no locality, ex Sladen coll., Ottawa (CNCO).

Distribution. Austria, Britain (England, Wales, Scotland), Bulgaria, Czech Republic, Finland, France, Germany, Ireland (new), Italy (new), Kirghizia (new), Netherlands (new), Romania, Russia (European part, new), Sweden, Switzerland (new), Taiwan, and Ukraine (new).

Biology. In southern Finland males have been captured between 28 June and 22 August, and females between 14 July and 27 August, both have a peak of occurrence at the end of July to beginning of August. All specimens captured in June in Europe are males, except one female on 23 June from Wales. The earliest males are from Tirol (4 June) and from Wales (10 June). The latest females have been captured in September: in N. Italy on 11 September, two females from Salzburg bear later dates but it is possible that they were not alive when taken. Host unknown. In
Austria and France the species has been found in nests of Bombus pascuorum (Scopoli)(syn. B. agrorum (Fabricius) and $B$. lapidarius (Linnaeus). In Janakkala and Riihimäki no specimens were captured near ageing logs of Pinus and $\mathrm{Pi}$ cea.

\subsubsection{Phrudus defectus Stelfox, 1966 (Fig. 7)}

Phrudus defectus Stelfox, 1966: 65. Lectotype female: Ireland, Co. Wicklow, Liffey Valley. Cloughleagh (USNM, Washington) (Fitton 1976: 349).

Both sexes of this species were originally described from Ireland and Northern Ireland. It has been recorded from Kent in England by Gauld \& Fitton (1980) and Germany (Hilpert 1989).

Description of female (based on females from England and Scotland). Length of fore wing 2.4$2.6 \mathrm{~mm}, 13-15$ flagellomeres. Black. Mandible yellowish brown, teeth amber red. Antenna dark brown. Palpi brownish, tegula and humeral plate brown, venation of fore wing and pterostigma dark brown, anal vein pale. Legs yellowish brown, coxae and femora darker brown, mid-coxae mostly and hind coxae almost completely black, tarsomeres 5 slightly infuscate, pecten of claws black.

Head 1.35 as wide as long in dorsal view, with temples hardly narrowing behind eyes, in anterior view 0.94 as high as wide. POL/OOL 0.53. Vertex and frons rather smooth, subshining, covered by short hairs all over, ocellar area with alutaceous microsculpture. Gena with narrow or broad glabrous zone behind eye in lateral view. Face transverse, 1.9 as wide as medially long, with fine transverse sculpture, densely hairy, upper medial hairs directed upwards. Clypeus rather faintly separated from face, strongly transverse, 3.0 as wide as high, lower margin weakly convex, medially rather thick, with irregular punctures, the longest setae submedially, all setae directed straight forward. Clypeal fovea rather small, narrow. Mandible with upper tooth longer than lower. Occipital carina complete, joining hypostomal carina distinctly above base of mandible. Maxillary palpi 5-segmented, labial palpi 3-segmented. Basal 3-5 flagellomeres distinctly elongate, the following ones gradually shorter and the subapical ones transverse. Flagellomeres 4 and 5 each 
with a small whitish tooth on basal (0.2) part of segment (Fig. 7).

Mesosoma 1.8 as long as wide, 1.23 as high as wide. Epomia hardly developed. Mesoscutum rather smooth, covered by short hairs all over, notauli finely impressed only near anterior margin, posteriorly indicated as shallow furrows or areas of microsculpture. Scutellum hairy, with punctures, posteriorly finely rugose, margined only near base. Epicnemial carina strong, not reaching anterior margin of mesopleuron, the rather weak lower anterior branch reaching anterior margin. Mesepisternum largely smooth, glabrous, postpectal carina broadly interrupted before midcoxa. Propodeum distinctly shorter than metasomal tergum 1, the anterior edge separated from metanotum by a deep furrow medially and laterally with the furrow shallow, with complete areolation except usually basal area and areola fused, its posterior area (areola) broader than anterior area or not. Costula distinct, variable in strength. Apical transverse carina usually strong, sometimes weak. Lateral boundary of areola normal or weak, the second lateral area often with longitudinal keels or faint carinae. Spiracle rather small, with rather thick walls. Fore femur stout, fore tibia with thin setae, without apical tooth on dorsal margin, fore tarsus shorter (0.92) than fore tibia, fore tarsomeres 3-4 transverse. Claws of fore and midclaws with strong pecten to apex. Hind femur 3.1 as long as high. Hind tibia about as long (1.02) as hind tarsus, inner spur slender, 0.55 as long as hind tarsomere 1 . Pecten of hind claws weaker, apex of claw broadly free. Pterostigma 2.6 as long as wide, radius leaving near the middle $(0.52)$. Areolet open, vein $3 \mathrm{~m}-\mathrm{c}$ absent. Nervulus postfurcal. Nervellus slightly reclivous, not broken.

Metasomal tergum 12.7 as long as apically wide, with spiracle before $(0.43)$ middle, dorsal profile moderately convex, glymma absent. Petiolus 1.6 as long as wide, 0.84 as high as wide. Postpetiolus 1.54 as long as wide, sternum 1 reaching anterior 0.42 level of postpetiolus. Tergum 2 slightly shorter than postpetiolus, transverse, 0.58 as long as wide in dorsal view, with minute thyridia on anterior margin, with spiracle before middle, with fine crease throughout lateral part. Tergum 31.18 as long as tergum 2, broadest of all, 0.60 as long as wide in dorsal view, following terga gradually shorter. Cercus hardly raised, ovoid, with setae. Ovipositor sheath narrow , slightly upcurved, 0.41 as long as hind tibia, ovipositor basally broad, in apical part narrow, 0.82 as long as hind tibia.

Description of male (English specimen). Fore wing $2.3 \mathrm{~mm}$ long, 17-16 flagellomeres. Colour as in female. Lower margin of clypeus medially thick, blunt, with large punctures. Antenna longer, all flagellomeres elongate, with numerous upright, curved hairs, flagellomeres 4-5 each with a small whitish tooth on basal part. Hind claws with pecten to apex. Metasomal tergum 12.4 as long as apically wide, with spiracles before $(0.41)$ middle, postpetiolus 1.5 as long as wide. Tergum 2 slightly shorter than postpetiolus, transverse, 0.58 as long as wide. Tergum 3 transverse, 0.52 as long as wide. Metasoma posterior to segment 11.8 as long as wide in dorsal view.

Variation. The number of flagellomeres and corresponding length of fore wing (mean and range in $\mathrm{mm}$ ) are as follows (not all specimens from Janakkala and Riihimäki measured):

$\begin{array}{lll} & \text { Flagellomeres, } & \text { fore wing } \\ \text { female; } & 11(\mathrm{n}=1) & 1.7 \\ & 12(\mathrm{n}=23) & 1.95(1.85-2.1) \\ & 13(\mathrm{n}=64) & 2.23(1.9-2.65) \\ & 14(\mathrm{n}=28) & 2.45(2.2-2.65) \\ & 15(\mathrm{n}=6) & 2.43(2.3-2.5) \\ \text { male; } & 14(\mathrm{n}=25) & 2.11(1.85-2.35) \\ & 15(\mathrm{n}=89) & 2.21(2.0-2.45) \\ & 16(\mathrm{n}=11) & 2.35(2.2-2.5) \\ & 17(\mathrm{n}=1) & 2.3\end{array}$

Specimens examined $\left(1035 \% 7860^{\circ}\right)$. Finland $(1015$ ㅇ $\left.782 \sigma^{\circ}\right)$. Ab: Särkisalo - Finby, 667:27, 19, leg. W. Hellén (ZMUH). Karkkila (labelled Pyhäjärvi), 671:34, 12.7.1958 1\%, leg. V. Vikberg (VVPC). N: Nurmijärvi, 6709:374, 17.7.1994 1 ơ, leg. M. Koponen (DAZH). Vantaa (labelled Helsingin pitäjä), 668:39, 2.7.1959 $10^{*}$, leg. V. Vikberg (VVPC). Ta: Riihimäki, 6736:379,

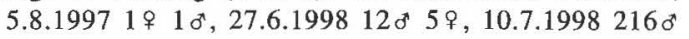
32 ㅇ, 17.7.1998 84 o $^{*} 13$ 우, 25.7.1998 31 o $^{*} 25$ \% 13.7.1999 1ㅇ, leg. V. Vikberg (VVPC). Janakkala, Turenki, 675:37, on pine logs, 8.7.1975 19; 6755:369, 9.7.1999 1 क; 6758:372, 16.6.1997 1ठ ; 17.6.1997 10; 20.6.1997 19 $1 \sigma^{7} ; 24.6 .19971 \sigma^{*} ; 3.7 .19971950^{*}$;

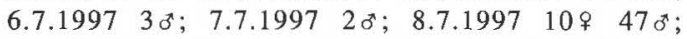
10.7.1997 6ㅇ 26

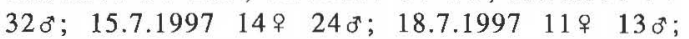
20.7 .199721 우 $190^{\circ} ; 21.7 .19976$ 우 $80^{\circ} ; 23.7 .19971$ 우

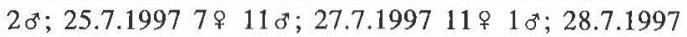
1 ㅇ $4 \sigma^{*} ; 31.7 .19976$ 웅 $2 \sigma^{\circ} ; 2.8 .19973$ \% $2 \sigma^{\circ} ; 3.8 .1997$

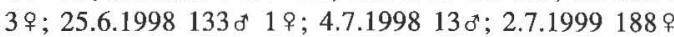
$22 \sigma^{*}$; 4.7.1999 $136932 \sigma^{\circ} ; 8.7 .199997$ क $160^{\circ} ; 12.7 .1999$ $145 \% 90^{\circ} ; 15.7 .1999179$ \% $50^{0} ; 21.7 .199933 \%$; 
27.7.1999 19\%; 1.8.1999 2\%; 7.8.1999 1\%; 9.8.1999 $1 \%$, leg. V. Vikberg (NHML, NMSE, RJPC, VVPC). Hattula, 676:34, on Pinus, 20.7.1982 4 o, leg. Y. Zhongqi (DAZH). Luopioinen, Padankoski, 6807:385, on Pinus and Picea logs, 16.7.1979 2\%, leg. V. Vikberg (VVPC). Heinola, 6788:449, 10.7.1999 25 9, leg. V. Vikberg (VVPC). Sa: Ristiina, 6826:502, 8.7.1978 1 $;$; 28.7.1979 1ㅇ; 6830:502, 25.6.1983 1ㅇ, leg. M. Koponen (DAZH). Mikkelin mlk., 6830:501, 5.7.1987 1; 6839:506, 19.8.1998 $1 \sigma^{*}$, leg. M. Koponen (DAZH). Ruokolahti, 679:59, woodpile of Pinus and Picea, 3.7.1975 2\%, leg. V. Vikberg (VVPC). Tb: Keuruu, 690:37, 10.8.1928 39, leg. W. Hellén (ZMUH). Obo: Yli-Ii, 7256:448, sweeping near wood pile of Pinus and Picea, 26.6.1979 1 9 , leg. M. Koponen (DAZH). Lkk: Kolari, 7469:365, window trap, 28.6.-5.7.1988 1ㅇ, leg. J. Siitonen (DAZH). Li: Utsjoki, 774:49, pit fall trap, 24.7.-4.8.1980 2o , leg. S. Koponen \& E. T. Linnaluoto (RJPC). Russia, Murmansk district, Kolttaköngäs (now Borisoglebskiy), 19301 온, leg. W. Hellén (ZMUH), Salmijärvi, $19303 \%$, leg. W. Hellén (ZMUH). Yläluostari (now Zapoljarnyj), 193010 , leg. W. Hellén (ZMUH). Sweden, SK: Röstanga, 4.7.1938 1 \%, leg. D. M. S. P. \& J. F. P. (NHML). England, Oxfordshire, Wychwood Forest, SP 335172, Malaise trap, 10.5.7.6.19913 910 (NMSE). Norfolk, Santon Downham, TL 818883, Malaise trap: heath with birch and pine, 21.5.30.5.1985 2ㅇ, leg. J. Field (NMSE). Scotland, Inverness, Cairngorms NNR, Rothiemurchus, NH 883055, Malaise trap in native pine, 16.7.-29.7.1985 4\%, leg. M. R. Shaw (NMSE). Germany, Bayern: München, Forstenried, Park, 10.8.1958 10 , leg. Haeselbarth (AEIG); Schliersee, $900 \mathrm{~m}, 23.6 .1968$ 1\%; Taufkirchen bei München, 26.6.1968 1ㅇ, leg. E. Haeselbarth (ZSSM). Hessen, Witzenhausen, 27.5.1967 1ळ, leg. E. Haeselbarth (ZSSM). Niedersachsen, Göttingen, Kalktrockenrasen, 31.7.1988 1ㅇ, leg. W. Ulrich (KHUW). Thüringen, 1 ㅇ, labelled Mengerssenia (!) paradoxa \& Schmied., Typus, coll. Schmiedeknecht (ZMHB), 1 \% similarly labelled except without Typus-label (AEIG). Ukraine, IvanoFrankovskaya oblast, $14 \mathrm{~km} \mathrm{~S}$ of Vorochta, $1000 \mathrm{~m}, P i$ cea woood, 24.7.1989 2\%, leg. Kasparyan (ZISP).

Distribution. Britain (England, Scotland), Finland (new), Germany, Ireland, Russia (European part, new), Sweden (new), and Ukraine (new).

Biology. In southern Finland the flight period is from 16 June to 10 August (one male on 19 August), but most specimens have been captured in July with a peak near the middle of the month. In England and Germany the earliest specimens have been captured at the end of May. In Ireland the original specimens were captured from 21 May to 11 June (Stelfox 1966). Host unknown. The species is clearly associated with Pinus sylvestris, and possibly with Picea abies. Specimens from Janakkala and Riihimäki ( $7800^{*} 953$ \%) were swept from bushes and low herbage around logs of Pinus, Picea etc.

\subsubsection{Phrudus compressus Vikberg sp. nov.}

Description of female. Holotype: Length of body $3.05 \mathrm{~mm}$, of fore wing $2.6 \mathrm{~mm}$. Black. Clypeus brownish black, mandible yellowish brown, apically amber red. Antenna dark brown, scape, pedicel and first two flagellomeres paler. Palpi, tegula and humeral plate yellowish brown. Wings clear, venation of fore wing and pterostigma dark brown, anal vein pale. Legs yellowish brown, coxae infuscate, nearly black. Tarsomeres 5 of all legs slightly infuscate, pecten of claws black.

Head 1.45 as wide as long in dorsal view, with temples hardly narrowing behind eyes, in anterior view 0.87 as high as wide. POL/OOL 0.58 . Vertex and frons smooth, shining, finely hairy all over, ocellar area with weak microsculpture. Face transverse, 2.4 as wide as medially high, with fine transverse sculpture, densely hairy. Clypeus very strongly transverse, 3.6 as wide as high, with lower margin weakly convex, medially rather thick, with irregular punctures. Malar space 0.62 as long as width of base of mandible. Mandible with upper tooth longer than lower. Occipital carina complete, joining hypostomal carina distinctly before mandible. Antenna with 16 flagellomeres, basal flagellomeres distinctly elongate, apical ones gradually becoming shorter, subapical ones slightly transverse. Flagellomeres 4 and 5 each with a small tooth on basal 0.2 .

Mesosoma 2.1 as long as wide, 1.38 as high as wide. Epomia hardly developed. Mesoscutum smooth, shining, covered with hairs all over, notauli finely impressed only near anterior margin. Scuto-scutellar fovea smooth, scutellum smooth, hairy, not margined. Epicnemial carina strong, not reaching anterior margin of mesopleuron. Mesopleuron smooth, shining, without striae on lower part, postpectal carina broadly interrupted anterior to mid-coxa. Propodeum distinctly shorter than metasomal segment 1 , posteriorly evenly sloping, with low carinae, anteriorly separated from metanotum by a deep, narrow furrow centrally and a shallow, $v$-shaped furrow laterally. Areola and basal area fused, costula weak, partly interrupted. Spiracle very small, round. Fore femur stout, fore tibia with thin setae, without apical tooth on dorsal margin, fore tarsus shorter (0.84) than fore tibia, fore tarsomeres 3-4 transverse. Claws of fore and mid-legs with strong pect- 
en to apex. Hind femur 3.3 as long as high, hind tibia and hind tarsus of the same length, inner spur of hind tibia slender, 0.46 as long as hind tarsomere 1. Pecten of hind claw not reaching to apex of claw. Pterostigma 3.0 as long as wide, radius leaving just before its middle $(0.48)$. Areolet partly open, vein $3 \mathrm{~m}-\mathrm{c}$ present only anteriorly. Nervulus postfurcal. Nervellus slightly reclivous, not broken, discoidella absent.

Metasoma posterior to segment 1 strongly compressed, ca 6.2 as long as wide in dorsal view. Tergum 1 long, narrow, 3.6 as long as wide, with spiracle before $(0.43)$ middle, dorsal profile moderately convex, glymma absent. Petiolus ca 2 times as long as wide, wider than high, postpetiolus 2.2 as long as wide, sternum 1 reaching anterior 0.21 of postpetiolus. Tergum 2 narrow, 1.8 as long as wide in dorsal view, with spiracle before middle and touching fine crease which extends the length of the tergum, laterotergite broad, oval thyridia present near posterolateral margins of postpetiolus. Tergum 3 almost (0.94) as long as tergum 2, the following terga gradually shorter. Ovipositor sheath narrow, slightly upcurved, 0.53 as long as hind tibia.

Description of male (from Janakkala). Length of fore wing $2.5 \mathrm{~mm}$. Antenna with 17 flagellomeres, preapical flagellomeres slightly elongate. Head not compressed, transverse, 1.6 as wide as long, temples narrowing behind eyes in dorsal view, in anterior view head is 0.86 as high as wide. Propodeum with shallow carinae as in female. Metasomal tergum 2 distinctly depressed, almost $(0.92)$ as long as apically wide, near basal margin with oval, oblique thyridiae, spiracle before middle and dorsal to crease which is present from base to apex. Posterior part of metasoma slightly compressed.

Variation. The number of flagellomeres and corresponding length of fore wing (mean and range in $\mathrm{mm}$ ) are as follows:

$\begin{array}{lll} & \text { Flagellomeres, } & \text { fore wing } \\ \text { female; } & 14(\mathrm{n}=21) & 2.26(2.1-2.45) \\ & 15(\mathrm{n}=93) & 2.39(2.1-2.7) \\ \text { male; } & 16(\mathrm{n}=47) & 2.59(2.4-2.8) \\ & 15(\mathrm{n}=3) & 2.05(1.9-2.2) \\ & 16(\mathrm{n}=24) & 2.28(2.05-2.55) \\ & 17(\mathrm{n}=28) & 2.36(2.15-2.55) \\ & 18(\mathrm{n}=2) & 2.55(2.5-2.6)\end{array}$

Specimens examined (150우 $\left.520^{\star}\right)$. Holotype female:
Finland. Ta: Janakkala, [Grid 27 ${ }^{\circ}$ E] 6758: 372, 10.7.1997 leg. V. Vikberg (DAZH). Paratypes: Finland. Ta: Riihimäki, $6736: 379,5.8 .19971$ क $1 \sigma^{*} ; 15.8 .199710 \% ; 19.8 .1997$ 4 ㅇ, 27.6.1998 3o, 10.7.199860 1 ㅇ, 17.7.1998 11 \% 5 ㅇ, 25.7.1998 3ㅇ, leg. V. Vikberg (VVPC). Janakkala, $6758: 372,2.8 .19961$ ㅇ ; 4.8.1996 3ㅇ; 5.8.1996 1우 1\%; 7.8.1996 2क; 8.8.1996 5; 10.8 .19961 우 21.8 .1996 $1 \% ; 27.8 .199619 ; 6.7 .19971920^{*} ; 8.7 .19975 \% 30^{*}$; 10.7.1997 6q $3 \sigma^{*} ; 11.7 .19976 \% 2 \sigma^{\circ} ; 13.7 .19978$ 우 8 o*; 15.7.1997 7우 $1 \sigma^{*} ; 18.7 .19973$ ㅇ 2 o ; 20.7.1997 14 우 $2 \sigma^{*} ; 21.7 .19977$ 우 $2 \sigma^{*} ; 23.7 .199711$ 우 3 d $^{\text {* }}$; 25.7.1997 6우 2 o; $27.7 .1997 \quad 3$ 우 28.7.1997 4우; 31.7.1997 2 우 2.8 .19973 우 3.8 .19977 우 6.8 .19971 우; 10.8 .19972 \%; 12.8 .19973 \% ; 31.8.1997 1\%; 2.7.1999 2 , 4.7.19992\%, 8.7.19993\%, 27.7.1999 1ㅇ, leg. V. Vikberg (DAZH, NHML, NMSE, RJPC, VVPC). Sweden. LU: Messaure, 13.7.1982 1, 21.7.1982 1 , leg. Karl Müller (AEIG).

Distribution. Finland, and Sweden (both new).

Biology. In southern Finland the flight period is from 27 June to 31 August, most specimens are from July with a peak near the middle of the month. Host unknown. All Finnish specimens (52 $0^{*} 148$ \%) were captured by sweeping bushes and low herbage near logs of Pinus sylvestris and Picea abies etc.

\subsubsection{Phrudus badensis Hilpert, 1987}

Phrudus badensis Hilpert, 1987a: 214. Holotype female: Germany, Baden-Württemberg, Bechtaler Wald in southern Baden, soil photoeclector 27.6.-3.7.1985, leg. H. Hilpert (ZSSM).

The female of the species was described and figured from Germany by Hilpert (1987a) based on five specimens. After that some females have been recorded in Cambridgeshire, England (Shaw 1991) and the species has been recorded from $N$. Italy (Scaramozzino 1995).

Description of female (from Janakkala). Fore wing $2.1 \mathrm{~mm}$ long, 12 flagellomeres. Black. Mandible yellowish brown, teeth amber red, palpi brownish, antenna dark brown, with base paler. Legs brownish yellow, coxae infuscate, hind coxae black, femora darker brown, tarsomeres 5 infuscate, pecten of claws black. Tegula and humeral plate yellowish brown, venation of fore wing and pterostigma dark brown. Ovipositor sheath dark brown.

Head smooth, shining, and strongly laterally compressed, 1.44 as long as wide in dorsal view, with temples subparallel behind eyes, 1.56 as high as wide in anterior view. Occiput concave above, 
occipital carina effaced mediodorsally, joining in an acute angle with hypostomal carina distinctly above base of mandible. Frons and vertex thickly hairy. Eyes distinctly hairy. Temples largely glabrous behind eyes in lateral view, slightly concave. Face narrow, ca 1.09 as long as wide, thickly hairy, upper medial hairs directed upwards. Clypeus distinctly separated from face, ca 2.7 as wide as medially high, medially above lower margin a little impressed, finely transversely striated, lower margin truncate, rather sharp. Malar space 1.2 as long as width of base of mandible. Upper tooth of mandible distinctly longer than lower. Antenna with all flagellomeres elongate, thickening towards apex, flagellomeres 4-5 each with a small tooth on basal (0.2-0.3) part.

Mesosoma laterally compressed, 3.0 as long as wide, 1.86 as high as wide. Epomia weak. Mesoscutum covered with thick, short hairs, notauli faintly impressed near anterior margin. Epicnemial carina reaching anterior margin of mesopleuron near lower corner of pronotum, mesepisternum with weak longitudinal striate microsculpture. Propodeum completely areolated, carinae fine, low. Area basalis and areola mostly fused, areola widest. Area petiolaris long, narrow, in profile rather straight. Fore tibia with fine setae, without apical tooth on dorsal margin, fore tarsus 0.8 as long as fore tibia. Hind femur 3.0 as long as high, hind tibia slightly shorter (0.92) than hind tarsus, with inner spur slender, 0.60 as long as hind tarsomere 1 . Fore and mid-claws with strong pectination to apex, hind claws with weaker pecten and apex broadly free.

Metasomal tergite 1 narrow, parallel, 4.2 as long as wide in dorsal view, with spiracle slightly before $(0.47)$ middle, upper profile moderately convex. Petiolus 2.4 as long as wide, posteriorly 1.05 as high as wide. Postpetiolus 2.3 as long as wide. Metasoma strongly compressed posterior to segment 1. Tergum 2 1.6-1.9 as long as broad, with oblique, oval thyridia near base, with spiracle in middle and crease throughout lateral part. Tergum 31.7 as long as wide. Ovipositor sheath narrow, 0.70 as long as hind tibia.

Description of male (from Janakkala). Fore wing $2.0 \mathrm{~mm}, 16$ flagellomeres. Black. Mandible, palpi as in female. Scape and pedicel yellowish brown, flagellum brownish black. Legs brownish yellow, coxae black, hind femur large- ly infuscate, tarsomeres 5 and hind tarsomere 4 infuscate. Head slightly compressed, 0.79 as long as wide in dorsal view, in anterior view 1.05 as long as wide. Eyes hairy. Temples convex, with large glabrous area behind eyes in lateral view. Occipital carina absent dorsomedially. Face 1.3 as wide as long medially. Clypeus 2.2 as wide as high, fore margin medially thicker, with large punctures. Flagellomeres more elongate than in female, with numerous upright, curved hairs, flagellomeres 4-5 each with a small tooth on basal part.

Mesosoma 2.1 as long as wide, 1.43 as high as wide. Hind femur 5.2 as long as high in lateral view. hind claws pectinate to apex.

Metasomal tergum 14.0 as long as wide, with spiracle slightly anterior $(0.44)$ to middle. Petiolus 2.5 as long as wide, posteriorly 0.82 as high as wide. Postpetiolus 2.3 as long as wide. Metasomal tergum 2 depressed, 1.17 as long as wide in dorsal view. Metasoma laterally compressed posterior to tergum 2,1.4 as high as wide. metasomal tergum 30.83 as long as wide. Metasoma posterior to tergum 3.2 as long as wide.

Variation. The number of flagellomeres and corresponding length of fore wing (mean and range in $\mathrm{mm}$ ) are given below (not all specimens from Finland measured):

$\begin{array}{lll} & \text { Flagellomeres, } & \text { fore wing } \\ \text { female; } & 12(\mathrm{n}=103) & 1.87(1.60-2.15) \\ & 13(\mathrm{n}=5) & 1.99(1.8-2.15) \\ \text { male; } & 14(\mathrm{n}=4) & 1.75(1.7-1.8) \\ & 15(\mathrm{n}=86) & 1.90(1.65-2.1) \\ & 16(\mathrm{n}=12) & 2.02(1.9-2.2)\end{array}$

Note 1. Examination of the collection of $\mathrm{W}$. Hellén (ZMUH) revealed that W. Hellén had recognized both $P$. defectus and $P$. badensis as valid species and given both a new name, but he never published anything about them.

Note 2. A species apparently very close to $P$. badensis was described about one month later than it from Taiwan, $P$. longius Chiu in Chiu \& Wong (1987). It has a similar head form but is still smaller: fore wing 1.3-1.5 mm long and male antenna with only 13 flagellomeres.

Specimens examined (288 $\left.96250^{\circ}\right)$. Finland (263 9 $\left.624 \sigma^{\circ}\right)$. Ta: Riihimäki, 6736:379, 5.8.1997 2\%; 15.8 .1997 13 우 30; ; 19.8.1997 2우 20; 2.9.1997 2우 27.6.1998

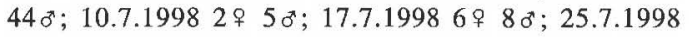
1 오, leg. V. Vikberg (VVPC). Janakkala, 6758:372,

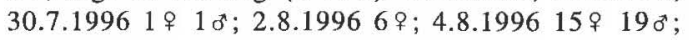


5.8 .19966 ㅇ $60^{*} ; 7.8 .19966$ 우 $1 o^{x} ; 8.8 .199611$ 우 $10^{*}$; $10.8 .19965 \delta^{\pi} ; 20.8 .19961$ \% ; 27.8.1996 $1 \sigma^{\pi} ; 12.6 .1997$ 1 우 13.6 .19974 \% 15.6 .19971 우 1 đ; 17.6 .19971 우 $6 \sigma^{*} ; 20.6 .19972$ 우 $3 \sigma^{*} ; 22.6 .19971$ क $8 \sigma^{*} ; 24.6 .1997$ 3 우 $13 \sigma^{*} ; 3.7 .19976$ ㅇ $17 \sigma^{*} ; 6.7 .19976$ ㅇ $32 \sigma^{*} ; 7.7 .1997$ 14 우 $27 \delta^{\pi} ; 8.7 .199712$ 우 51 o ; 10.7 .199710 우 $400^{\pi}$;

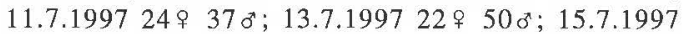
15 क $34 \sigma^{*} ; 18.7 .19974 \sigma^{*} ; 20.7 .199712$ \% 43 o; 21.7.1997 4ㅇ $24 \sigma^{x} ; 23.7 .19973$ 우 $5 \sigma^{*} ; 25.7 .19972$ \%; 27.7.1997 4 \& $2 \sigma^{*} ; 28.7 .19977$ ㅇ $11 \sigma^{*} ; 31.7 .19972 \sigma^{*}$;

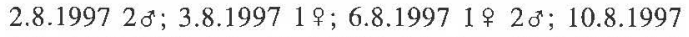
1 우; 12.8 .19971 우; 17.8 .19971 우 3 율 28.8.1997 1 우

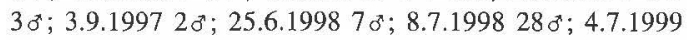
1우 15.7.1999 1; 21.7.1999 1; 27.7.1999 1 $o^{x}$; 9.8.1999 1 \%, leg. V. Vikberg (NHML, NMSE, RJPC, VVPC). Hattula, Takajärvi, 677:34, 11.6.1921 1 o*, leg. W. Hellén (ZMUH). Sa: Ristiina, 6826:502, 6.7.1996 1ㅇ, leg. M. Koponen (DAZH). Mikkelin mlk., 6830:501, 22.6.1979 1 $\sigma^{*} ; 30.7 .19802 \sigma^{*} ; 12.7 .19813 \% 2 \sigma^{*} ;$ 30.7.1986 1ब; 5.7.1987 2क 1 đ; $17.7 .19871 \%$; 18.7.1987 1 우 3 đ $^{*} ; 27.7 .19903$ 우 2 क ; 30.7 .19902 우 $1 \sigma^{*} ; 27.6 .19921$ 우 $2 \sigma^{*} ; 18.7 .19932$ đ; $10.6 .19954 \sigma^{*}$; 12.6 .19951 우 2 đ; 6837:503, 30.7.1990 1\%; 8.7.1996

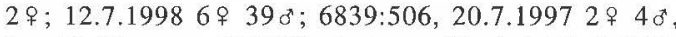
leg. M. Koponen (DAZH). Joutseno, Honkalahti, 678:57, 22.7.1945 $10^{*}$, leg. W. Hellén (ZMUH). Kl: Parikkala, Laurila, 683:63, 23.7.1945 1 $\delta^{*}$, leg. W. Hellén (ZMUH). Russia, Leningrad region, Viipuri (now Vyborg), 25.6.1920 19, leg. E. Thuneberg (ZMUH). England, Berkshire, Silwood Park near Ascot, Malaise trap, summer 1995, 1\% leg. D. Quicke (NHML). Cambridgeshire, Chippenham Fen, TL 650693, Malaise trap: carr at reedbed edge, 18.8.-28.8.1983 1 우 ; ca. 19841 ㅇ; 29.6. 9.7.1984 1 우 9.7.-20.7.1984 1우 20.7.-1.8.1984 5우 ; 1.8.-15.8.1984 2\%; 15.8.-27.8.1984 1 \% 1 \% ; 27.8. 27.9.19841\%; 25.6.-5.7.19851\%; 25.6.-8.7.19851\%; 20.7.-30.7.1985 1우 30.7.-11.8.1985 1ㅇ, leg. J. Field (NMSE). Norfolk, Santon Downham, TL 818883, Malaise trap: heath with birch and pine, 16.6.-25.6.1983 1 우 6.7.-20.7.1985 1; 20.7.-30.7.1985 1의, leg. J. Field (NMSE). Germany, Baden Württenberg: Ettlinger, Buchenwald, 12.7.1982 2 \% (paratypes of Phrudus badensis), leg. Beck (KHUW). Italy, Piemonte, Castelnuovo DB-AT, 250 SLM, May 1974, 1 ㅇ leg. D. Gianasso (RJPC).

Distribution. Britain (England), Finland (new), Germany, Italy, and Russia (European part, new).

Biology. In southern Finland the flight period is from 11 June to 3 September, but most specimens are from July with a peak on 10-12 July. Host unknown. The species is clearly associated with Pinus sylvestris and possibly also with $P i$ cea abies. Specimens from Janakkala and Riihimäki were swept from bushes and low herbage near logs of Pinus and Picea, males (554 specimens) were caught more frequently than females (238 specimens). Specimens from Mikkeli rural municipality were netted near a woodpile of $P i$ nus, Picea, Betula, Alnus. The host is unknown but obviously associated with pine logs and wood piles, particularly old wood with bark containing tunnels and exit holes of several different species of Coleoptera.

\section{Discussion}

The subfamily Phrudinae was established by Townes \& Townes (1949). The characters of the redefined subfamily were discussed and the genera included were described and figured by Townes (1971). In that work ten genera were treated (one of them, Peucobius, new from N. America), Seleucus was included in the subfamily and Astrenis was included in Phrudus. Since then two genera have been described: Lygurus from the E. Palaearctic area (Kasparyan 1983b) and Notophrudus from the temperate part of southern Chile (Porter 1993). The subfamily contains small representatives in the Holarctic area and temperate Chile and large representatives in tropical regions (Africa and America). Gauld (1997) gave the latest diagnosis of the subfamily and according to him both forms have one synapomorphy (narrow proboscidal fossa) and are thus related. Gauld still included Seleucus in Phrudinae and Astrenus in Phrudus.

Our work is the first serious attempt to treat all European species of Phrudinae. Of 3290 European specimens examined 3050 (92.7 percent) are from Finland and 240 specimens ( 7.3 percent) from other European countries. 10 species occur in northern Europe and all of them, except Astrenis paradoxus, have been found in Finland. Eight species are listed as Swedish, but none have been recorded yet from Denmark, Norway, the Karelian Republic or Estonia. The highest numbers of species in Finland are from provinces $A b$ : 5, N: 5, Ta: 7 and Sa: 6 (Fig. 17). Collecting activity has, however, been most intensive in that area.

Below we discuss two interesting characters of the Phrudinae: the modified sensory structures on the subbasal flagellomeres and the structure (teeth) of tarsal claws. Author VV noticed that both females and males of Phrudinae have modified sensory structures on the dorsolateral surface of the subbasal flagellomeres. Kasparyan (1983a) had already noticed corresponding struc- 

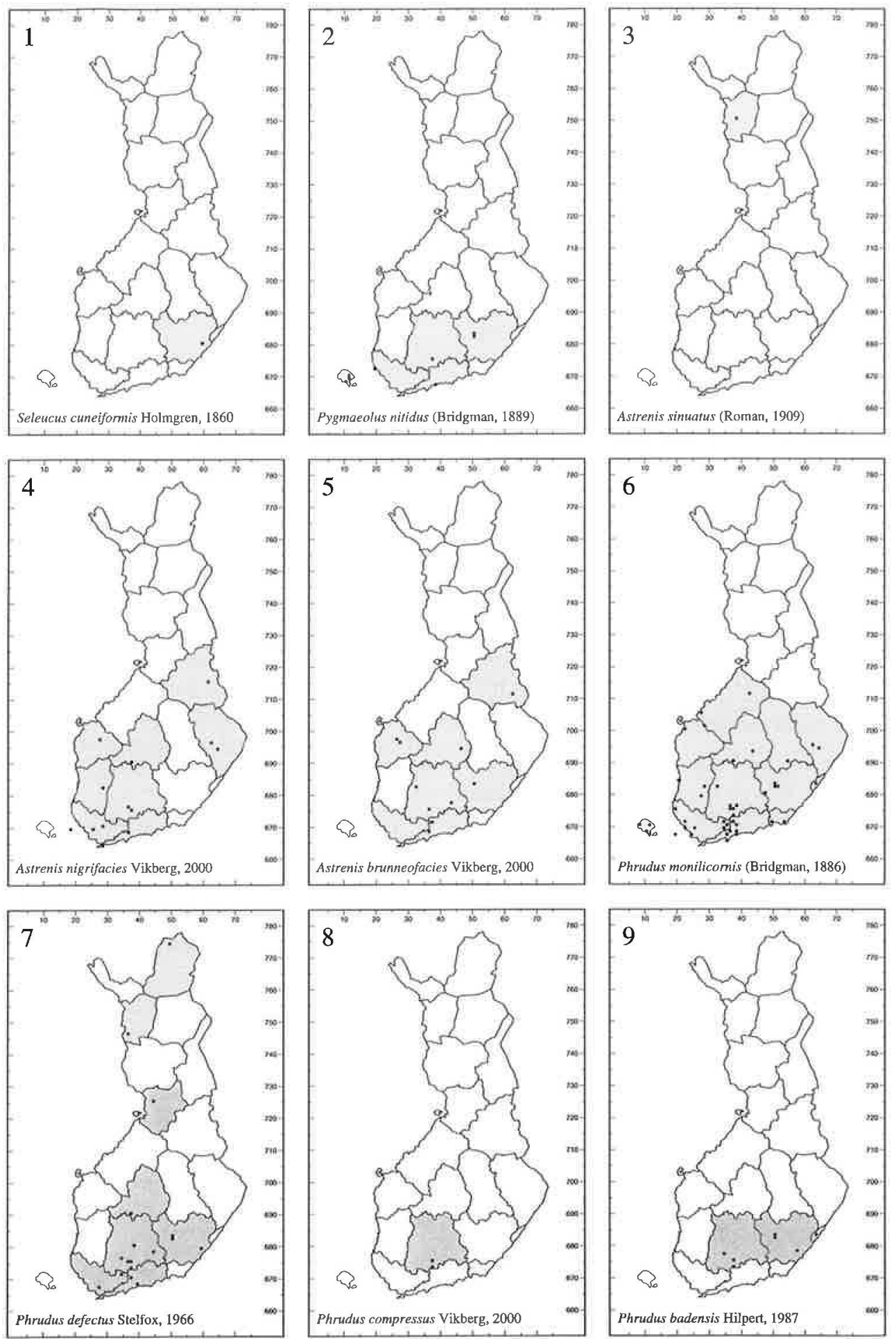

Fig. 17. Distribution maps of Seleucus cuneiformis Holmgren and 8 species of Phrudinae in Finland. 
tures on the antennae of three species of Phaestacoenitus Smits van Burgst: "characteristic sensory structures in the form of rounded impressions on 4th to 6th flagellar segments of both sexes, not occurring in other ichneumonids." The basal part of the female antenna of $P$ h. caucasicus was figured by Kasparyan (1983a) and the sensory structures appear to be near the middle of the segments on the distal half, they are shown as oval with a black spot basally which may represent a tooth. The following forms were found in the species studied by us: Phaestaconitus niger nitidus: flagellomeres 4-6 with whitish tooth inside hollow on apical 0.6 part of segment; Pygmaeolus nitidus: small tooth on apical (0.7) part of flagellomeres 4-6 (\%) or 4-7 ( $\left.\sigma^{*}\right)$; Earobia paradoxa: flagellomere 3 with a large oval impressed area of whitish sensilla on apical half; Astrenis, all 4 species: small tooth on apical (0.6-0.8) part of flagellomeres 3-6(7); Phrudus monilicornis; long, curved spine arising near the base of flagellomeres 4-8; P. defectus, compressus, badensis: small, often white, tooth on the basal $(0.2-0.4)$ part of flagellomeres 4-5.

Why such sensory structures have evolved is unclear nor do we know if females use them for the same purpose as males. Phrudinae much resemble some Tersilochinae although Wahl (1993) belives the similarity to be superficial. However, some Tersilochinae appear to have rather similar structures: two females from England representing two different species: Probles (Rugodiaparsis) crassipes (Thomson) and Epistathmus crassicornis Horstmann have a small narrow whitish tooth on the apical margin of each of flagellomeres 4-7. Some other species (both females and males) of Finnish tersilochines have similar structures. Perhaps Phrudinae and Tersilochinae are closely related to each other (sister groups ?); species of both subfamilies attack larvae of Coleoptera. It could be worthwhile to make a thorough study of the sensory structures of subbasal flagellomeres in Tersilochinae and other subfamilies of Ichneumonidae using a scanning electron microscope.

The structure of the pecten on tarsal claws was found to be a useful character in Astrenis and Phrudus. Seleucus cuneiformis, Phaestacoenitus niger nitidus, Pygmaeolus nitidus and Earobia paradoxa have simple claws. In European spe- cies of Phrudus the pecten is black, strong and similar in all species, but in the hind claws there is a difference between sexes: in the male the hind claws have a strong pecten to the apex as on fore and mid-claws, but in the female the pale apex of the claw is free and clearly visible (so there is a mistake in the text of Fig. 6 in Gauld \& Fitton (1980); either the sex is wrong, or if correct, then the figure represents the fore or mid-claw). In Astrenis the pecten is strongest in fore claws, weaker in mid-claws and weakest in hind claws; Astrenis females have stronger teeth than males (opposite to the situation in the hind claws of Phrudus). The situation in Astrenis resembles that of Blacus (Ganychorus), subfamily Blacinae of the Braconidae (see e.g. van Achterberg 1988), as in that subgenus the teeth of the fore claw are the strongest, of the hind claw the weakest and of the mid-claw intermediate (some species of that subgenus are also associated with logs of Pinus and are parasitoids of Coleoptera). The two types of claws in Astrenis were figured in Gauld \& Fitton (1980): Figs 7-8; they do not belong to the same species, as indicated in the legend of their figures. Fig. 7 fits $A$. nigrifacies (= sinuatus group) well and Fig. 8 fits A. brunneofacies (= paradoxus group).

Often males in Ichneumonidae have more flagellomeres than their females. In Phrudinae this is mostly the situation: Pygmaeolus nitidus male has one more than the female, Phrudus monilicornis one more, $P$. defectus two more, $P$. compressus one more, and $P$. badensis 2-3 more because the female has a rather fixed low number. Astrenis species in our material appear to have equally many in both sexes but the number of specimens examined is rather low. Males of Taiwanese species of Astrenis have one to two flagellomeres more than females (Chiu \& Wong 1987).

In all species of Phrudinae larger body size is correlated with higher number of flagellomeres. This is evident from the number of flagellomeres and corresponding mean length of fore wing in different species.

Very little is known about the biology of European species of Phrudinae, except of Earobia paradoxa. During the fieldwork for this study we made small advances; some of the species were clearly associated with bark-coated Pinus and $P i$ - 
cea logs etc. These have a rich fauna of different kinds of Coleoptera some of which are undoubtedly hosts of Phrudinae. Therefore, further research could be directed to these bark-coated logs and the soil beneath them in order to clarify how adults of Phrudinae attack their host larvae, or they could perhaps be reared from soil beneath the logs.

Acknowledgements. We would like to thank all the curators of the entomological collections mentioned in the Material and Methods for loan of specimens under their care, especially the following: Anders Albrecht, Erich Diller, Mike Fitton, Jürgen Götze, Klaus Horstmann, John Huber, Lars-Åke Janzon, Reijo Jussila, Dimitry Kasparyan, Frank Koch, Suzanne Lewis, David Notton, Mark Shaw, and David Wahl. Alexey Zinovjev acted as a courier with specimens from ZISP. Hans Silfverberg helped us when additional information on specimens collected by Wolter Hellén was taken from Hellén's collecting notebook. Kwei-shui Lin, Taiwan Agricultural Research Institute, kindly sent the publication of Chiu \& Wong (1987), copies of which were also received from David Smith, Smithsonian Institution and David Wahl. Klaus Horstmann confirmed the identification of the two species of Tersilochinae mentioned in the discussion. Anders Albrecht helped us to make the maps of the distributions of the species in Finland. Mark Shaw and an unknown referee commented the manuscrift and suggested several improvements. Mark Shaw carefully checked the descriptions and the terms, corrected them and improved our English. Viktor Benno Meyer-Rochow also checked our English.

\section{References}

Achterberg, C. van 1988: Revision of the subfamily Blacinae Foerster (Hymenoptera, Braconidae). - Zool. Verh. Leiden 249: 1-324, figs. 1-1250.

Aerts, W. 1957: Die Schlupfwespen- (Ichneumoniden-) Fauna des Rheinlandes. - Decheniana 109(2): 137 212.

Arillo, A. \& Sanz de Bremond, C. 1992: La entomofauna fosil del Mioceno superior de la depresion ceretana. Himenopteros. (Fossil entomofauna from upper Miocene of Cerdanya Basin. Hymenoptera). - Graellsia 48: 99-107. (In Spanish with English summary)

Aubert, J. F. 1957: Révision des travaux concernant les Ichneumonides de France et premier supplément au catalogue de Gaulle. - Entomophaga 2: 213-243.

Aubert, J. F. 1976: Ichneumonides non pétiolées inédites ou mal connues. - Bulletin de la Sociéte Entomologique de Mulhouse 1976 (juillet-août-septenbre): $25-32$.

Aubert, J. F. 1979: Huit Ichneumonides [non] pétiolées inédites (I). - Bulletin de la Société Entomologique de Mulhouse 1979 (avril-juin): 17-22.

Aubert, J. F., Halperin, J. \& Gerling, D. 1984: Les Ich- neumonides d'Israel. - Entomophaga 29(2): 211235.

Bridgman, J. B. 1886: Further additions to the Rev. T. A. Marshall's catalogue of British Ichneumonidae. Trans. Entomol. Soc. Lond. 1886: 335-373.

Bridgman, J. B. 1889: Further additions to the Rev. T. A. Marshall's catalogue of British Ichneumonidae. Trans. Entomol. Soc. Lond. 1889: 409-439.

Brischke, C. G. A. 1880: Die Ichneumoniden der Provinzen West- und OstPreussen. I. Fortsetzung. Schriften der Naturforschenden Gesellschaft in Danzig N. F. 4(4): 108-210.

Cameron, P. 1905: On some Hymenoptera (chiefly undescribed) collected by Prof. C. F. Baker in Nevada and southern California. - Invertebrata Pacifica 1: 120 132.

Carlson, R. W. 1979: Family Ichneumonidae. - In: Krombein, K. V., Hurd, Jr. P. D., Smith, D. R. \& Burks, B. D. (eds.), Catalog of Hymenoptera in America North of Mexico 1, Symphyta and Apocrita (Parasitica): 315-740. Smithsonian Institution Press, Washington, D. C. xvi \& 1198 pp.

Carr, L. A. 1924: The Ichneumonidae of the Lichfield District, Staffordshire, - Transactions of the North Staffordshire Field Club 58(Append): 1-70.

Chiu, S. C. \& Wong, C. Y. 1987: The Phrudinae of Taiwan (Hymenoptera: Ichneumonidae). - Taiwan Agric. Res. Inst., Special Publ. 22: 1-18.

Cushman, R. A. 1927: Miscellaneous notes and descriptions of Ichneumon-flies. - Proc. U. S. Natn. Mus. 72(2709): 1-22.

Dalla Torre, C. G. de 1901-1902: Catalogus Hymenopterorum hucusque descriptorum systematicus et synonymicus 3. Trigonalidae, Megalyridae, Stephenidae, Ichneumonidae, Agriotypidae, Evaniidae, Pelecinidae. - Guilelmi Engelmann, Lipsiae. 1901: 1544. 1902: 545-1141.

Fitton, M. G. 1976: The western Palaearctic Ichneumonidae (Hymenoptera) of British authors. - Bull. Brit. Mus. (Nat. Hist.) Entomology 32(8): 301-373.

Förster, A. 1869: Synopsis der Familien und Gattungen der Ichneumonen. - Verh. Naturh. Ver. Preuss. Rheinl. 25(1868): 135-221.

Franz, J. M. 1958: Studies on Laricobius erichsonii Rosenh. (Coleoptera: Derodontidae). A predator on chermesids, part 1, Distribution, life-history and ecology. - Entomophaga 3(2): 109-164.

Gauld, I. D. 1997: Ichneumonidae of Costa Rica, 2. Introduction and keys to species of the smaller subfamilies, Anomaloninae, Ctenopelmatinae, Diplazontinae, Lycorininae, Phrudinae, Tryphoninae (excluding Netelia) and Xoridinae, with an appendix on the Rhyssinae. - Mem. Amer. Entomol. Inst. 57: i-vii, $1-485$.

Gauld, I. D. \& Fitton, M. G. 1980: The British species of Phrudinae (Hym., Ichneumonidae). — Entomologist's Mon. Mag. 115 (1979): 197-199.

Goulet, H. \& Huber, J. T. (eds.) 1993: Hymenoptera of the world: An identification guide to families. - Research Branch, Agriculture Canada, Ottawa. i-vii, 1668.

Habermehl, H. 1925: Beiträge zur Kenntnis der palaeark- 
tischen Ichneumonidenfauna. - Konowia 4: 1-19.

Hedwig, K. 1939: Verzeichnis der bisher in Schlesien aufgefundenen Hymenopteren V. Ichneumonidae. Zeitschrift fr Entomologie, Breslau 18(3): 12-28.

Hedwig, K. 1940: Verzeichnis der bisher in Schlesien aufgefundenen Hymenopteren V. Ichneumonidae. Zeitschrift für Entomologie, Breslau 18(4): 12-18.

Hedwig, K. 1950: Ichneumoniden der Umgebung von Würzburg (einzelne von der Rhön u. Lohr). - Nachrichten des Naturwissenschaftlichen Museums der Stadt Aschaffenburg 29: 43-56.

Hedwig, K. 1959: Entomologische Beobachtungen in der Braunschweiger Börde. Ein Beitrag zur Fauna der parasitisch lebenden Hymenopteren und ihrer Wirte. - Verhandlungen des Vereins für naturwissenschaftliche Heimatforschung 34: 32-47.

Heinrich, G. H. 1937: Ichneumoninae Pokucia. - Polskie Pismo Entomologiczne 14-15(1935-1936): 122143.

Hellén, W. 1942: Zur Ichneumonidenfauna Finnlands (Hym.) III. - Notulae Entomol. 22: 76-87.

Hellén, W. 1946: Zur Ichneumonidenfauna Finnlands (Hym.) V. - Notulae Entomol. 26: 1-12.

Hellén, W. 1959: Zwei verschollene Ichneumonidenarten (Hym.) - Notulae Entomol. 38(1958): 83-86.

Hilpert, H. 1987a: Eine neue Art der Gattung Phrudus Foerster (1868) (Hymenoptera, Ichneumonidae, Phrudinae), - Entomofauna 8(10): 213-219.

Hilpert, H. 1987b: Erster Beitrag zur Kenntnis der südbadischen Schlupfwespenfauna. Ichneumoniden des Feldberggebietes I. Faunistik (Hymenoptera, Ichneumonidae). - Mitteilungen des Badischen Landesvereins für Naturkunde und Naturschutz 14(2): 343360.

Hilpert, H. 1987c: Schlupfwespen des Feldberggebietes (Hymenoptera, Ichneumonidae). - Carolinea 45: 147-158.

Hilpert, H. 1989: Zur Hautflüglerfauna einer südbadischen Eichen-Hainbuchenmischwaldes. -- Spixiana 12(1): 57-90.

Holmgren, A. E. 1860: Försök till uppställing och beskrifning af de i Sverige funna ophionider (Monographia Ophionidum Sueciae). - K. Svensk. Vet. Akad. Handl., n. f., 2(8): 1-158.

Horstmann, K. 1971: Revision der europäischen Tersilochinen (Hymenoptera, Ichneumonidae) Teil I. Veröff. Zool. Staatssamml. München 15: 45-138.

Horstmann, K. 1988: Die Schlupfwespenfauna der Nordsee-Inseln Mellum und Memmert (Hymenoptera, Ichneumonidae). Drosera 88: 183-206.

Horstmann, K. 1990: Revision einiger Typen der von Otto Schmiedeknecht beschriebenen paläarktischen Ichneumonidae (Hymenoptera). - Beiträge zur Entomologie Berlin 40(1): 31-61.

Jussila, R. 1984: Ichneumonidae (Hymenoptera) of Inari Lapland. - Kevo Notes 7:83-99.

Kasparyan, D. R. 1981: Subfamily Phrudinae. - In: Kasparyan, D. R. (edit.): (Keys for the identification of insects of European part of USSR) 3. Hymenoptera, part 3: 348-351. Nauka, Leningrad, $688 \mathrm{pp}$. (In Russian)

Kasparyan, D. R. 1983a: Three new species of the icneu- monid genus Phaestacoenitus Smits (Hymenoptera, Ichneumonidae) from the Caucasus and Middle Asia. - Entomologicheskoye Obozreniye 62(1): 153-156. (In Russian). English translation in Entomol. Review Wash. 62(1)1983: 141-145.

Kasparyan, D. R. 1983b: A new eastern Palaearctic genus of the subfamily Phrudinae (Hymenoptera, Ichneumonidae). - Contributions Am. Entomol. Inst. 20: $116-118$.

Kazmierczak, T. 1991: Ichneumonidae (Hymenoptera) of the surroundings of Gastein in the Alps Part II. Acta Zoologica Cracoviensia 34(1): 65-98.

Kazmierczak, T. 1993: Ichneumonidae (Hymenoptera) of selected regions of southern Poland. - Acta Zoologica Cracoviensia 36(1): 77-120.

Kolarov, J. A. 1984: Ichneumonidae (Hymenoptera) new for Bulgarian fauna. - Universite de Plovdiv "Paissi Hilendarski" Travaux Scientifiques 22: 59-69.

Kolarov, J. A. 1987: A new Ctenopelmatinae genus and species from Bulgaria (Hymenoptera, Ichneumonidae). - Entomofauna 8(6): 69-76.

Kolarov, J. A. 1993: Über die Taxonomie einiger Ichneumoniden (Hymenoptera, Ichneumonidae). - Linzer biol. Beitr. 25(2): 1093-1097.

Kolarov, J. A. 1995: A catalogue of the Turkish Ichneumonidae (Hymenoptera). - Entomofauna 16(7): 137-188.

Lange, C. 1898: Ergebnisse entomologischer Beobachtungen aus der Umgebung Annabergs X. - Ber. Annaberg-Buchholzer Ver. Naturkunde 1898: 53-104.

Maneval, H. 1935: Observations sur des Hyménoptères de la faune française et description d'une espèce nouvelle, - Revue Française d'Entomologie 2: 65-76.

Morley, C. 1911: Ichneumonologia Britannica. The Ichneumons of Great Britain. 4. Tryphoninae. - London, xvi \& 344 pp.

Morley, C. 1915: Ichneumonologia Britannica. The Ichneumons of Great Britain. 5. Ophioninae. - London, $400 \mathrm{pp}$.

Perkins, J. F. 1953: Notes on British Ichneumonidae with descriptions of new species (Hym., Ichneumonidae). - Bull. Brit. Mus. (Nat. Hist.) Entomology 3: 103176.

Perkins, J. F. 1958: Description of Echtrolaricobius paradoxus n. g. n. sp. - In: Franz, J.M. Studies on Laricobius erichsonii Rosenh. (Coleoptera: Derodontidae), a predator on Chermesids. Entomophaga 3: 146-148.

Perkins, J. F. 1962: On the type species of Foerster's genera (Hymenoptera: Ichneumonidae). - Bull. Brit. Mus. (Nat. Hist.) Entomology 11(8): 383-483.

Pfankuch, K. 1935: Verzeichnis der Ichneumoniden von Bremen und Umgegend. -- Mitteilungen aus dem Entomol. Verein in Bremen 21(1934): 6-30.

Porter, C. C. 1993: First record of Phrudinae (Hymenoptera: Ichneumonidae) from South America with notice of a new genus and species from Chile. - J. New York Entomol. Soc. 101(1): 130-134.

Rey del Castillo, C. 1991: Primera cita de Adelognathinae, Neorhacodinae y Phrudinae de España (Hymenoptera, Ichneumonidae). (First record of Adelognathinae, Neorhacodinae and Phrudinae from Spain). 
- Boletín de la Asociación Española de Entomologia 15: 153-163. (In Spanish with English abstract)

Roman, A. 1909: Ichneumoniden aus dem Sarekgebirge. - In: Hamberg, A., Naturwissenschaftliche Untersuchungen des Sarekgebirges in Schwedisch-Lappland (Zool.) 4(3): 199-374. [Centraltryckeriet, Stockholm. 175 pp.]

Roman, A. 1914: Beiträge zur schwedischen Ichneumonidenfauna. - Arkiv Zool. 9(2): 1-40.

Roman, A. 1925: Schwedische Schlupfwespen, alte und neue. - Arkiv Zool. 17A(4)(1924): 1-34.

Roman, A. 1931: Insektenfaunan inom Abisko nationalpark: II. Studier under ledning av Yngve Sjöstedt, 4. Parasitsteklar - Ichneumonidae. - Kongliga Svenska Vetenskapsakademiens Skrifter i Naturskyddsårenden 17: 4-54.

Sawoniewics, J. 1982: Ichneumonidae (Hymenoptera) of Warzaw and Mazovia. - Memorabilia Zoologica 36: 5-39.

Sawoniewics, J. 1986: Structure of Ichneumonidae (Hymenoptera) communities in urban green areas of Warzaw. - Memorabilia Zoologica 41: 103-139.

Scaramozzino, P. L. 1995: Hymenoptera Ichneumonidae. - In: Minelli, A., Ruffo, S. \& La Posta, S. (eds.), Checklist delle specie della fauna Italiana. Fascicolo 94: 1-62. Edizioni Calderini, Bologna.

Schmiedeknecht, O. 1906: Opuscula Ichneumonologica. 2, Cryptinae. Fasc. 13: 963-998.

Schmiedeknecht, O. 1907: Die Hymenopteren Mitteleuropas nach ihren Gattungen und zum grossen Teil auch nach ihren Arten analytisch bearbeitet. - Gustav Fischer, Jena, VII \& 804 pp.

Schmiedeknecht, O. 1910: Opuscula Ichneumonologica. 4. Ophioninae. Fasc. 26: 2001-2080.

Schmiedeknecht, O. 1912: Opuscula Ichneumonologica. 5, Tryphoninae. Fasc. 32: 2483-2562.

Schmiedeknecht, O. 1930: Fam. Ichneumonidae. - In: Schmiedeknecht, O. (ed.), Die Hymenopteren Nordund Mitteleuropas mit Einschluss von England, Südschweiz, Südtirol und Ungarn nach ihren Gattungen und zum grossten Teil auch nach ihren Arten analytisch bearbeitet: 82-337. 2. edn., Verlag von Gustav Fischer, Jena. x \& 1062 pp.

Šedivý, J. 1989: Ichneumonidae. — In: Šedivý, J. (ed.): Enumeratio insectorum Bohemoslovakiae. Check list of Czechoslovak insects III. Hymenoptera: p. 49-94. Acta Faunistica Entomologica Musei Nationalis Pragae 19: 1-195.

Seyrig, A. 1932: Observations sur les Ichneumonides (3e série). - Annales de la Société Entomologique de France 101: 111-126.

Shaw, M. R. 1991: Phrudus badensis Hilpert (Hym., Ich- neumonidae) new to Britain. - Entomologist's Mon. Mag. 127: 157-158.

Smits van Burgst, C. A. L. 1913: Ichneumonidae, II. Entomologische Berichten Nederl. Ent. Ver. 3: 363367.

Starke, H. 1956: Ichneumonidenfauna der sächsischen Oberlausitz. - Natura Lusatica (Bautzen) 3: 17-92.

Stelfox, A. W. 1966: Description of a second Britannic species of the genus Phrudus (Hym., Ichneumonidae). - Entomologist's Mon. Mag. 102: 65-66.

Strob1, G. 1901: Ichneumoniden Steiermarks (und der Nachbarländer). - Mittheilungen des Naturwissenschaftlichen Vereins für Steiermark (Graz) 37(1900): $132-257$.

Strobl, G. 1904: Ichneumoniden Steiermarks (und der Nachbarländer) V. Fam. Ophionidae. - Mitteilungen des Naturwissenschaftlichen Vereins für Steiermark (Graz) 40(1903): 43-160.

Thomson, C. G. 1888: [XXXVII.] Biddrag till Sveriges insectfauna. - Opuscula Entomologica 12: $1202-$ 1265.

Townes, H. K. 1967: Taxonomic notes on Kentrotryphon, Ktenostilpnus, and Parentypoma. - Proc. Entomol. Soc. Washington 69(1): 58-59.

Townes, H. K. 1969: The genera of Ichneumonidae, part 1. - Mem. Am. Ent. Inst. 11: 1-300.

Townes, H. K. 1970: The genera of Ichneumonidae, part 3. - Mem. Am. Ent. Inst. 13(1969): 1-307.

Townes, H. K. 1971: The genera of Ichneumonidae, part 4. - Mem. Am. Ent. Inst. 17; i-iii, 1-372.

Townes, H. K., Momoi, S., \& Townes, M. 1965: A catalogue and reclassification of the eastern Palearctic Ichneumonidae. - Mem. Am. Ent. Inst. 5: i-v, 1661.

Townes, H. K. \& Townes, M. 1949: A revision of the genera and of the American species of Tryphoninae Part I. - Annals of the Entomological Society of America 42: 321-395.

Townes, H. K. \& Townes, M. 1951: A revision of the genera and of the Nearctic species of Grypocentrini. - Proc. Ent. Soc. Washington 53(6): 301-313.

Uchida, T. 1940: - Kontyu Kenkyu 4: p. 10. (reference not seen)

Wahl, D. B. \& Sharkey, M. J. 1993: Superfamily Ichneumonoidea. - In: Goulet, H. \& Huber, J. T. (eds.), Hymenoptera of the world: An identification guide to families: 358-509. Research Branch, Agriculture of Canada, Ottawa. vii \& 668 pp.

Yu, D. S. \& Horstmann, K. 1997: A catalogue of World Ichneumonidae (Hymenoptera). Part 2: Subfamilies Orthocentrinae to Xoridinae. - Mem. Am. Ent. Inst. 58 (2): 764-1558. 